\title{
THE VANISHING CORE OF JUDICIAL INDEPENDENCE
}

\begin{abstract}
Evan C. Zoldan*
With Congress firmly in control of the jurisdiction, resources, and structure of the federal courts, the scope of the judiciary's independence is limited indeed. If there is an attribute that can be considered the core of judicial independence, it is the power of the federal courts to decide cases pending before them. In a pair of recent decisions, however, the Supreme Court has called into question whether the federal judiciary possesses even this limited attribute of independence. This Article examines how the Court has blurred the line between the judicial and legislative powers by ceding to Congress the authority to direct federal courts to decide pending cases for particular parties. After identifying the thorny issues that the Court has left unsettled, this Article suggests an approach to resolving them that preserves both Congress's role in lawmaking as well as the core of the judiciary's independence.
\end{abstract}

\section{TABLE OF CONTENTS}

INTRODUCTION 532

I. THE VANISHING CORE OF JUDICIAL INDEPENDENCE ............................ 538

A. The Core of Judicial Independence ............................................... 538

1. Attributes of Judicial Independence .........................................538

2. The Core of Judicial Independence ........................................ 544

a. Competing Visions of the Core of Judicial Independence ................................................................. 544

b. A Proposed Core of Judicial Independence ..................... 546

B. $\quad$ The Vanishing Core of Judicial Independence ............................ 551

1. Klein's Rule of Decision Principle ........................................... 551

2. The Evisceration of Klein ................................................... 552

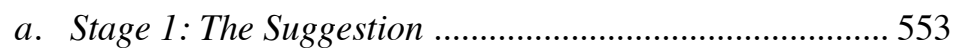

* Professor of Law, University of Toledo College of Law. My thanks to Vicki C. Jackson, Henry P. Monaghan, Stephen B. Burbank, Charles G. Geyh, Tara Leigh Grove, William D. Araiza, Emily Berman, David Kwok, Brooke D. Coleman, Elizabeth McCuskey, Daniel Klerman, Richard Heppner, and Kiel Brennan-Marquez for their insights and comments on earlier drafts of this Article and related work. My thanks also to participants in the Civil Procedure Workshop, Central States Law School Association Annual Conference, the Loyola University Chicago Constitutional Law Colloquium, and the SEALS Public Law Works-inProgress Program. Thanks also to the University of Toledo College of Law for its support for this project. 


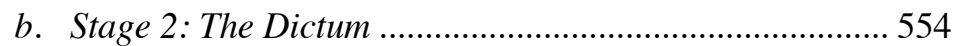

c. Stage 3: The Holding ...................................................... 554

II. PATChaK: A LAST GASP OR NEW LIFE FOR JUdiCIAL

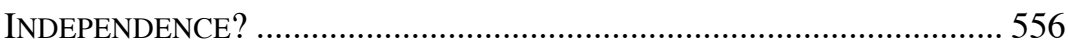

A. The Plurality .......................................................................... 557

B. Ginsburg and Sotomayor's Concurrences ................................... 558

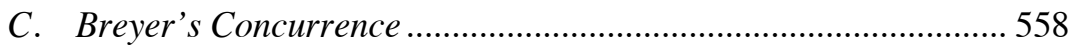

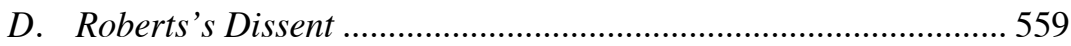

III. A CHANCE FOR JUDICIAL INDEPENDENCE …....................................... 560

A. The Changed Law Rule ........................................................... 561

1. The Overbreadth of Thomas's Approach ................................561

2. Three Narrower Approaches ..................................................562

B. The Constitutionality of Targeted Legislation ............................. 566

1. A Constitutional Value of Legislative Generality .................... 566

2. Applying a Value of Legislative Generality ........................... 568

C. A "Class of Cases" ..................................................................... 571

1. A Class of Cases v. a Single Case ............................................... 571

2. A Class of Cases v. Pending Cases Only ............................. 574

D. The Government's Sovereign Immunity ....................................... 577

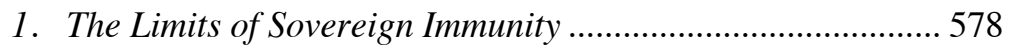

2. A Principle Against Self-Dealing.............................................. 579

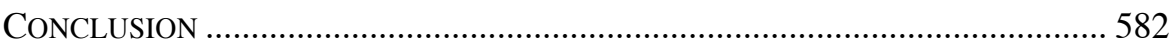

\section{INTRODUCTION}

When the history of the Roberts Court is written, the independence of the judiciary will be one of its central themes. Indeed, Roberts's preoccupation with the decisional independence of judges - that is, whether individual judges make decisions free of bias - was evident even before his confirmation as Chief Justice. In a well-known exchange during his Senate confirmation hearing, then-Judge Roberts proclaimed his vision of judicial independence: "Judges are like umpires. Umpires don't make the rules, they apply them. ... [A]nd I will remember that it's my job to call balls and strikes, and not to pitch or bat." "As Chief Justice, Roberts has continued to emphasize his vision of the judicial role, explaining that judges "do not advance political positions;" "[we] do not sit on opposite sides of an aisle, we do not caucus in separate rooms, we do not

${ }^{1}$ Confirmation Hearing on the Nomination of John G. Roberts, Jr. to be Chief Justice of the United States: Hearing Before the Comm. on the Judiciary, 109th Cong. 55-56 (2005) [hereinafter John Roberts Confirmation Hearing] (statement of John G. Roberts, Jr., Nominee to be Chief Justice of the United States).

2 Joan Biskupic, The Chief: The Life and Turbulent Times of Chief Justice John ROBERTS 11 (2019). 
serve one party or one interest. We serve one nation." 3 And in a remarkably pointed public defense of the courts in the face of growing accusations of their partisan leanings, the Chief Justice responded: "[w]e do not have Obama judges or Trump judges, Bush judges or Clinton judges. What we have is an extraordinary group of dedicated judges doing their level best to do equal right to those appearing before them." 4

Although Roberts is not alone in asserting that judges exercise decisional independence, ${ }^{5}$ skeptics often overshadow the defenders of this position. ${ }^{6}$ Perhaps most vociferously, former President Trump made clear his position that judges who ruled against his favored policies in litigation are "activists," that the Court of the Appeals for the Ninth Circuit is "out of control," and that the United States court system itself is "broken and unfair." Perhaps not surpris-

3 University of Minnesota Law School, The 2018 Stein Lecture: John G. Roberts, Jr., Chief Justice of the United States, YouTuBE (Oct. 22, 2018), https://www.youtube.com/watch?v=9 i3RwW0y_kE [https://perma.cc/2LWX-X4C5]; see also Jeffrey Rosen, Roberts's Rules, ATLANTIC (Jan./Feb. 2007), https://www.theatlantic.com/magazine/archive/2007/01/robertssrules/305559/ [https://perma.cc/FFF8-6DLC] (describing Roberts's interest in the public's perception of the Court as an "impartial institution that transcends partisan politics").

${ }^{4}$ Mark Sherman, Roberts, Trump Spar in Extraordinary Scrap Over Judges, Associated PRESS (Nov. 21, 2018), https://apnews.com/c4b34f9639e141069c08cf1e3deb6b84 [https://pe rma.cc/BUG6-AEZW]. Perhaps Chief Justice Roberts's insistence on the independence of the judiciary stems from the concern that a loss of the public's support could lead to a loss of the judiciary's power. Political science literature suggests that Supreme Court justices "have strong incentives to be concerned with their public standing. They recognize that erosion of public support and institutional legitimacy has negative consequences for the Court's power and institutional integrity." Tom S. Clark, The Separation of Powers, Court Curbing, and Judicial Legitimacy, 53 Am. J. PoL. SCI. 971, 973 (2009).

5 Bill Mears, O'Connor: Don't Call Us 'Activist Judges,' CNN (Nov. 28, 2006, 2:31 PM), http://www.cnn.com/2006/POLITICS/10/27/mears.judicialindependence/index.html [https:// perma.cc/8XLU-EACS] (reporting statements from Justices O'Connor and Breyer about the importance of judicial independence).

${ }^{6}$ Stephen B. Burbank, The Architecture of Judicial Independence, 72 S. CAL. L. Rev. 315, 315 (1999) (noting that attacks on judicial independence have "become part of orchestrated strategies of political parties and other groups").

7 In His Own Words: The President's Attacks on the Courts, BrenNAN CTR. FOR Just. (Feb. 14, 2020), https://www.brennancenter.org/our-work/research-reports/his-own-words-preside nts-attacks-courts [https://perma.cc/664M-PZ78]. While much of President Trump's rhetoric is unique to him, the amorphous accusation of "judicial activism" has a long history: Republican Party platforms since at least 1996 have insisted that judicial activism is a feature of judges appointed by Democrats. President George W. Bush campaigned on the promise of appointing "strict constructionist" judges rather than "liberal activist judges." Neil S. Siegel, Interring the Rhetoric of Judicial Activism, 59 DePAul L. REV. 555, 557-58, 564 (2010). Accusations of judicial activism come from the political left, as well. Dean Chemerinsky characterized the Supreme Court's Citizens United decision as "a stunning example of judicial activism by its five most conservative justices." Erwin Chemerinsky, Conservatives Embrace Judicial Activism in Campaign Finance Ruling, L.A. Times (Jan. 22, 2010, 12:00 AM), https://www.latimes.com/archives/la-xpm-2010-jan-22-la-oe-chemerinsky22-2010jan2 2-story.html [https://perma.cc/A9N2-GDUG]; see also Charles G. Geyh, Judicial Independence, Judicial Accountability, and the Role of Constitutional Norms in Congressional Regu- 
ingly, some commentators have argued that the general public also tends to view the Supreme Court in partisan terms, reposing their confidence in the Court when a president from their preferred party successfully appoints a justice and withdrawing their confidence when the appointment is made by a president from the opposing party. ${ }^{8}$

Even if Roberts's "balls and strikes" metaphor rings hollow to many, ${ }^{9}$ there is widespread agreement that judges should exercise decisional independence when adjudicating individual disputes. ${ }^{10}$ However, there is less agreement about whether the judiciary has or should have institutional independence, ${ }^{11}$ that is, whether there is some judicial authority that cannot be controlled by the political branches. ${ }^{12}$ There are a number of values that have been attributed to

lation of Congress, 78 IND. L.J. 153, 155 (2003) (noting the bipartisan nature of accusations of judicial activism).

8 Jeffrey M. Jones, Trust in Judicial Branch Up, Executive Branch Down, GalluP (Sept. 20, 2017), https://news.gallup.com/poll/219674/trust-judicial-branch-executive-branch-down.asp x [https://perma.cc/7BQU-NM49] ("With conservative Justice Neil Gorsuch joining the Supreme Court in April, Republicans' trust in the judicial branch has surged over the past year .... Democrats are now less trusting in the federal judiciary."). Scholars debate the extent to which members of the public tend to support the Court even if it does not rule "their way." Tara Leigh Grove, The Supreme Court's Legitimacy Dilemma, 132 HARV. L. REV. 2240, 2252 (2019) (reviewing Richard H. FAllon, JR., LAW AND Legitimacy in the SUPREME COURT (2018)).

9 Charles Fried, Balls and Strikes, 61 EMORY L.J. 641, 641 (2012) (“John Roberts has been both praised and scorned for the metaphor he presented to the Senate Judiciary Committee at the hearing on his confirmation to be Chief Justice of the United States: '[I]t's my job to call balls and strikes." "); Jon D. Michaels, Baller Judges, 2020 WIS. L. REV. 411, 413 ("[Judges] shouldn't style themselves umpires because, quite frankly, umpire-judging is often impossible in any case involving anything more than fact or credibility adjudication.").

${ }^{10}$ E.g., Vicki C. Jackson, Packages of Judicial Independence: The Selection and Tenure of Article III Judges, 95 GEO. L.J. 965, 967 (2007) (“'A]ll who act as judges are expected to exercise independent judgment, in the sense of being impartial as between the parties and not having a personal stake in the dispute ...."); John A. Ferejohn \& Larry D. Kramer, Independent Judges, Dependent Judiciary: Institutionalizing Judicial Restraint, 77 N.Y.U. L. REV. 962, 965 (2002) (arguing that it is universally agreed that "decisional independence, meaning judges' ability to adjudicate facts and interpret law in particular cases 'free from any outside pressure: personal, economic, or political, including any fear of reprisal' " is a virtue).

11 Jackson, supra note 10 ("While all who act as judges are expected to exercise independent judgment ... there is disagreement about how independent from the public, or from elected political branches, judges should be in interpreting and applying the law."); Geyh, supra note 7, at 160 ("We can only hypothesize as to whether Congress has the power or authority to punish a judge for making an unpopular decision by labeling it a high misdemeanor and removing her on that basis, or by cutting her budget, or abolishing the judgeship she occupies, or by depriving the federal courts of jurisdiction ....").

12 Burbank, supra note 6, at 320 (arguing that the standard view of judicial independence assures that "judges free of congressional and executive control will be in a position to determine whether the assertion of power against the citizen is consistent with law"); Charles Gardner Geyh \& Emily Field Van Tassel, The Independence of the Judicial Branch in the New Republic, 74 CHI.-Kent L. Rev. 31, 32 (1998) (proposing that judicial review requires 
independence in this institutional sense; most saliently, institutional independence allows judges to uphold rights of citizens against the government ${ }^{13}$ and police disputes among its three branches. ${ }^{14}$ Chief Justice Roberts emphasized the importance of the institutional independence of the courts as well, explaining that the federal courts are tasked with ensuring that the political branches act within the confines of the law..$^{15}$

Despite these justifications for institutional independence, there are also good reasons for the political branches to exert at least some control over the judiciary. After all, another way to describe judicial dependence is judicial $a c$ countability. Judges are unelected and cannot be removed except under unusual circumstances; as a result, dependence on the political branches can be seen as an indispensable mechanism for ensuring that judges apply law that has been enacted through democratic channels. ${ }^{16}$ Moreover, it is possible to overstate the tension between judicial accountability and judicial independence. Professor Burbank has argued that judicial independence and judicial accountability can be thought of as "complementary concepts" rather than "concepts at war with each other."17

But, no matter whether judicial independence and judicial accountability are complementary or in tension with one another, the relationship between these two concepts manifests itself in a number of seemingly intractable conceptual and doctrinal problems. This Article considers one of these perennial problems: whether Congress may direct a federal court to decide a pending dispute for a particular party. On one hand, the power to write laws for courts to follow is squarely part of Congress's lawmaking authority. ${ }^{18}$ On the other hand,

that "the courts possess the means to protect their institutional integrity against unconstitutional political branch encroachments").

${ }^{13}$ Ferejohn \& Kramer, supra note 10, at 968 (“[P]olitical actors face pressures to abandon or subvert legal rules for legally inappropriate reasons."); Jackson, supra note 10, at 969 (noting that judges were made independent to, inter alia, "protect minorities from popular passions").

14 Jackson, supra note 10, at 969 (noting that judges were made independent to, inter alia, "check the other branches of government when they departed from the fundamental commitments set forth in the Constitution").

15 University of Minnesota Law School, supra note 3.

${ }^{16}$ Ferejohn \& Kramer, supra note 10, at 965 ("Yet everyone also agrees that certain forms of popular or legislative pressure are not only permissible, but indispensable."); Jackson, supra note 10, at 997 ("Legitimate constitutional government, moreover, requires both independent courts and effective democratic participation in governance.").

17 Stephen B. Burbank, What Do We Mean by "Judicial Independence"?, 64 Оніо ST. L.J. 323,325 (2003) ("An accountable judiciary without any independence is weak and feeble. An independent judiciary without any accountability is dangerous.").

18 See U.S. ConST. art. I, §1 ("All legislative Powers herein granted shall be vested in a Congress of the United States....”); James E. Pfander, Principles of Federal JURISDICTION 405 ( $3 \mathrm{~d}$ ed. 2016) (noting that applying rules of decision is precisely what courts do). 
courts are empowered to adjudicate disputes pending before them. ${ }^{19}$ Most of the time, these two powers coexist without any conceptual or practical difficulty: after Congress writes a generally applicable law, a court applies the law to a particular factual situation. However, conflict arises when Congress writes a law that is so narrow that it guarantees the outcome in a particular, pending case. When it writes a statute with this level of specificity, Congress walks perilously close to the line that separates the judicial power from the legislative power. ${ }^{20}$

Now is the right time to reconsider the fuzzy line separating the legislative and judicial functions. Widespread criticism of the federal courts, including increasingly pointed accusations of political bias, have precipitated renewed popular and scholarly interest in measures to curb the influence of the federal courts, ${ }^{21}$ including proposals to strip the federal courts of jurisdiction over particular subject matters. ${ }^{22}$ The Supreme Court, too, has waded into the murky subject of judicial independence in a pair of recent cases, Bank Markazi v. Peterson $^{23}$ and Patchak v. Zinke. ${ }^{24}$ In these cases, the Court considered statutes that explicitly picked a winning party in a pending case and directed the federal court to rule accordingly. In both of these cases, the Court upheld the statutes. In doing so, the Court expanded the scope of Congress's authority to make law at the expense of the judiciary's power to adjudicate. How far Congress may expand its authority at the expense of the judicial power is the subject of this Article.

In Part I, I will argue that the core of judicial independence is vanishing. By constitutional design, Congress is firmly in control of the jurisdiction, re-

${ }^{19}$ U.S. CONST. art. III, $§ 1$ ("The judicial Power of the United States, shall be vested in one supreme Court, and in . . . inferior Courts ....").

${ }^{20}$ For a discussion of the line between the judicial and legislative power, see Evan C. Zoldan, The Klein Rule of Decision Puzzle and the Self-Dealing Solution, 74 Wash. \& LeE. L. REV. 2133, 2148-72 (2017) [hereinafter Zoldan, Klein].

${ }^{21}$ Tom S. Clark, The Limits of Judicial IndePENDENCE 5-6 (2011).

${ }^{22}$ Christopher Jon Sprigman, Congress's Article III Power and the Process of Constitutional Change, 95 N.Y.U. L. REV. 1778, 1780-81 (2020) (arguing for broad congressional power under the Exceptions Clause); Tara Leigh Grove, The Origins (and Fragility) of Judicial Independence, 71 VAND. L. REV. 465, 471 (2018) (arguing that political actors treat many court-curbing measures as out of bounds although this restraint is not compelled by constitutional text, structure, or history); Ronald J. Krotoszynski, Jr. \& Atticus DeProspo, Against Congressional Case Snatching, 62 WM. \& MARY L. ReV. 791 (2021) (arguing for a broad rendering of a principle that prevents Congress from directing federal courts to reach particular judgments in pending cases).

${ }^{23}$ Bank Markazi v. Peterson, 136 S. Ct. 1310, 1322-23 (2016). For a discussion and critique of Bank Markazi, see Evan C. Zoldan, Bank Markazi and the Undervaluation of Legislative Generality, 35 Yale L. \& PoL'y L. Rev. InTER Alia 1, 1 (2016) [hereinafter Zoldan, Bank Markazi].

${ }^{24}$ Patchak v.Zinke, 138 S. Ct. 897, 905 (2018). 
sources, and structure of the federal courts. ${ }^{25}$ Congress's control is so pervasive, in fact, that scholars have long struggled to articulate what authority, if any, stands at the core of the judiciary's independence. ${ }^{26}$ After considering different possible formulations of judicial independence, I conclude that the core of judicial independence should be seen as the courts' authority to decide disputes pending before them without legislative direction. This version of the core of judicial independence comports with persuasive normative accounts of judicial independence, ${ }^{27}$ is consistent with the Supreme Court's prohibition on the revision or reopening of final judgments, ${ }^{28}$ and is rooted in the "Klein rule of decision" principle, named for a Reconstruction-era case that invalidated an attempt by Congress to direct the result in pending cases. ${ }^{29}$ After describing the contours of the core of judicial independence, I will then argue that this core is vanishing. The modern Supreme Court has narrowed it through a series of doctrinal limitations on its scope, culminating in its Bank Markazi opinion.

In Part II, I will unpack the potential implications of the Court's Patchak case on the vanishing core of judicial independence. Patchak's fractured opinions raise more questions than they answer about the vitality and scope of the rule of decision principle. I will explore whether Patchak reflects the last gasp of air for judicial independence or whether, instead, Patchak breathes new life into its core. Patchak, although it should have been an easy case after Bank Markazi, unsettles the issues that Bank Markazi seemingly laid to rest. The Patchak opinions assert, in stark terms, diametrically opposed visions of the rule of decision principle and judicial independence more generally.

In Part III, I will address the issues that Patchak tees up, but does not settle, about the scope of the Klein rule of decision principle and, along with it, the core of judicial independence. After exploring the dispute underlying each of these issues, I will suggest how the courts, including the Supreme Court, should

${ }^{25}$ Geyh, supra note 7, at 160 (arguing that judicial independence "is diminished by Congress's powers to establish, and by negative implication, disestablish the lower courts, and to curb the Supreme Court's jurisdiction").

${ }^{26}$ For thorough discussions of the structural relationships and practices that make up judicial independence, see Jackson, supra note 10, at 992 (describing the features that make up judicial independence); John Ferejohn, Independent Judges, Dependent Judiciary: Explaining Judicial Independence, 72 S. CAL. L. REV. 353, 355 (1999) (same); Geyh \& Van Tassel, supra note 12, at 31-32 (same); ABA COMM'N ON SEPARATION OF POWERS AND JUD. INDEP., AN INDEPENDENT JUDICIARY 10-11 (1997) [hereinafter ABA COMM'N].

${ }^{27}$ Ferejohn, supra note 26, at 366-67 (arguing that judicial independence protects the "rule of law," that is, "making sure that powerful people-particularly elected officials-cannot manipulate legal proceedings to their advantage").

${ }^{28}$ Hayburn's Case, 2 U.S. (2 Dall.) 409, 411-12 (1792) (holding that "revision and control" of federal court judgments by the executive is inconsistent with judicial independence); Plaut v. Spendthrift Farm, Inc. 514 U.S. 211, 225-26 (1995) (holding that Congress may not require the federal courts to reopen final judgments).

${ }^{29}$ United States v. Klein, 80 U.S. (13 Wall.) 128, 146 (1871) (holding unconstitutional a withdrawal of jurisdiction "founded solely on the application of a rule of decision, in causes pending, prescribed by Congress"). 
approach them in a future case. There are no easy answers to the issues raised in Patchak, but their proper resolution can preserve the core of judicial independence while still recognizing Congress's lawmaking role.

\section{The VANishing CoRe of Judicial INDEPENDENCE}

Judicial independence is easy to praise and difficult to define. It is clear that no impermeable barrier stands between judges and outside influence; yet, there is no agreement about whether there are, or should be, any limits to Congress's ability to control the federal courts. In this Part, I argue that the core of judicial independence is the power of the courts to decide cases that are pending before them without legislative direction. But, this core of judicial independence is vanishing. The Supreme Court has blurred, if not erased, the line separating the judicial and legislative functions. Through a series of decisions upholding statutes that intrude on the power of the courts to decide pending cases, the Supreme Court has all but ceded the core function of the courts to Congress.

\section{A. The Core of Judicial Independence}

Rather than turning on a single necessary and sufficient feature, judicial independence is better characterized as the product of structures and practices that describe both judicial behavior and the larger governmental system in which it resides. As a result, before articulating the core of judicial independence, I begin with a description of its attributes.

\section{Attributes of Judicial Independence}

Judicial independence is often celebrated as the "backbone of our uniquely American liberties" 30 or even essential to a free society. ${ }^{31}$ And it is no wonder; an independent judiciary is believed to protect any number of widely held values. These values are often stated in negative terms - that is - they free judges from certain unacceptable influences. If judges are financially independent of the parties whose cases they adjudicate, for example, they can resolve disputes free of bias caused by self-interest or fear of reprisal. ${ }^{32}$ Moreover, a judge

30 Joseph M. Hood, Judicial Independence, 23 J. NAT'L Ass'N AdMIN. L. JudGES 137, 144 45 (2003).

31 ABA Comm'N, supra note 26, at iii (“Over two hundred years of experience confirm the wisdom of our nation's founders that judicial independence is the 'most essential characteristic of a free society." ").

${ }^{32}$ Ferejohn, supra note 26, at 355 ("[J]udicial independence is the idea that a judge ought to be free to decide the case before her without fear or anticipation of (illegitimate) punishments or rewards."); Geyh \& Van Tassel, supra note 12, at 31 ("[Judicial] independence concerns the impartiality of judges - the capacity of individual judges to decide specific cases on the merits, without 'fear or favor." "); Ferejohn \& Kramer, supra note 10, at 965 (argu- 
whose position and salary are not dependent on any particular case's outcome can render decisions free from political pressure, whether from elected officials directly ${ }^{33}$ or from interest groups. ${ }^{34}$ Stated in positive rather than negative terms, independent judges are free to interpret the law and decide cases according to the substantive legal commitments embodied in the rules they apply. ${ }^{35}$

Despite these laudable justifications for an independent judiciary, judicial independence is not absolute. As scholars have often described, the robustness of judicial independence turns on whether it refers to the decisional independence of individual judges or the institutional independence of the judicial branch as a whole. ${ }^{36} \mathrm{~A}$ judge has decisional independence to the extent she is "free to decide the case before her without fear or anticipation of (illegitimate) punishments or rewards." ${ }^{37}$ It is decisional independence that Chief Justice Roberts invokes when he stresses that judges are merely calling balls and strikes. ${ }^{38}$ And it is decisional independence that is questioned when judges are accused of ruling in line with political biases rather than impartially, on the facts and law before them. ${ }^{39}$

ing that judicial independence includes freedom from "any outside pressure: personal, economic, or political, including any fear of reprisal").

${ }^{33}$ Geyh \& Van Tassel, supra note 12, at 31-32 (arguing that judicial independence protects the "capacity of the judiciary to remain autonomous, so that it might serve as an effective check against the excesses of the political branches").

${ }^{34}$ Burbank, supra note 6, at 329 (arguing that judicial independence plays a role in "protecting us from the day-to-day depredations of interest-group politics"); Jackson, supra note 10, at 969 (noting that judicial independence was intended, in part, to "protect minorities from popular passions that would violate their legal rights").

35 Jackson, supra note 10, at 969 (arguing that judges were made independent, in part, "to judge according to law; they were to have the independence to interpret the law in order to render judgment"); Ferejohn \& Kramer, supra note 10, at 967 (arguing that interference from political actors "threatens to undermine the substantive commitments embodied in law through partial applications").

${ }^{36}$ Ferejohn, supra note 26, at 355("Independence seems to have at least two meanings. One meaning ... is that a person is independent if she is able to take actions without fear of interference by another.... Another meaning ... applies naturally to courts and to the judicial system as a whole."); Geyh \& Van Tassel, supra note 12, at 31 ("Decisional independence concerns the impartiality of judges .... Branch or institutional independence, on the other hand, concerns the general, non-case specific separation of the judicial branch ....").

${ }^{37}$ Ferejohn, supra note 26, at 355; see also Ferejohn \& Kramer, supra note 10, at 965 (defining decisional independence as "judges' ability to adjudicate facts and interpret law in particular cases 'free from any outside pressure: personal, economic, or political, including any fear of reprisal"').

38 John Roberts Confirmation Hearing, supra note 1 ("Judges are like umpires. Umpires don't make the rules, they apply them.... [A]nd I will remember that it's my job to call balls and strikes, and not to pitch or bat."); Geyh, supra note 7, at 162 ("If we want judges to 'call 'em like they see 'em' - to decide cases on the basis of facts as they find them and law as they construe it to be written-then we must insulate them from external influences that could corrupt their integrity or impartiality."). Cf. Michaels, supra note 9, at 411, 413.

39 See Eric A. Posner, Does Political Bias in the Judiciary Matter? : Implications of Judicial Bias Studies for Legal and Constitutional Reform, 75 U. CHI. L. REV. 853, 858 (2008) ("Po- 
The decisional independence of individual judges is supported by the Constitution's salary and tenure protections as well as unwritten cultural norms..$^{40}$ Once confirmed, Article III of the Constitution provides tenure during "good behavior" and compensation that cannot be diminished. ${ }^{41}$ These tenure and salary protections are designed to permit judges to make decisions without fear of retaliation from the political branches. ${ }^{42}$ Although tenure is qualified by the possibility of removal after impeachment and conviction, ${ }^{43}$ this power is seldom used ${ }^{44}$ Indeed, of the thousands of Article III judges who have served since the beginning of the Republic, only fifteen have been impeached and, of those, only seven have been removed from office..$^{45}$

Compared with the decisional independence of individual judges, the institutional independence of the judiciary is far less secure. The judiciary is independent in the institutional sense to the extent that it has authority that cannot be invaded by the political branches. ${ }^{46}$ But, because Congress is in control of

litical bias refers to partisan or ideological bias: the desire for an outcome to the left (or right) of a (stipulated) impartial outcome."); Jackson, supra note 10, at 967 (“[A]ll who act as judges are expected to exercise independent judgment, in the sense of being impartial as between the parties and not having a personal stake in the dispute ....").

${ }^{40}$ Grove, supra note 22, at 467-68 (arguing that political actors treat many court-curbing measures as out of bounds although this restraint is not compelled by constitutional text, structure, or history).

${ }^{41}$ U.S. CONST. art. III, $\S 1$ ("The Judges, both of the supreme and inferior Courts, shall hold their Offices during good Behaviour, and shall, at stated Times, receive for their Services, a Compensation, which shall not be diminished during their Continuance in Office."); see Ferejohn, supra note 26, at 355 (noting that judges are more or less independent while the judiciary as an institution is more or less dependent on the political branches).

${ }^{42}$ Jackson, supra note 10, at 967 (noting that tenure and salary protections protect judges from consequences of unpopular decisions).

${ }^{43}$ Compare U.S. Const. art. I, § 2 ("The House of Representatives . . shall have the sole Power of Impeachment."), with U.S. ConST. art. I, § 3 ("The Senate shall have the sole Power to try all Impeachments.").

${ }^{44}$ See Josh Chafetz, Congress's Constitution 148-50 (2017) (describing impeachment as a seldom used but important congressional power); Ferejohn \& Kramer, supra note 10, at 980 ("Over the course of American history only thirteen [now fifteen] judges have been impeached and only seven removed from office; four were acquitted and two more resigned before their trials in the Senate.").

${ }^{45}$ Impeachments of Federal Judges, FED. JudiCIAL CTR., https://www.fjc.gov/history/judges/ impeachments-federal-judges [https://perma.cc/88S6-M5QY] (listing each impeachment and conviction of a federal judge). Because the House and Senate could, but do not, use the impeachment and conviction process more aggressively, their forbearance can be seen as part of the customary independence of the judiciary. See Geyh, supra note 7, at 158 (noting the "gradual decline over the nineteenth and twentieth centuries in the acceptability of holding the judiciary accountable for its decisions by means of impeachment ...."). Professor Grove has pointed out that some judges might resign rather than face the impeachment process.

${ }^{46}$ Burbank, supra note 6, at 320 (arguing that the standard view of judicial independence assures that "judges free of congressional and executive control will be in a position to determine whether the assertion of power against the citizen is consistent with law"); Geyh \& Van Tassel, supra note 12, at 32 (proposing that judicial review requires that "the courts 
the budget, jurisdiction, and structure of the federal courts, the judiciary as a branch is better described as largely dependent on Congress rather than independent of it. ${ }^{47}$ Although the Constitution, not Congress, creates the Supreme Court, ${ }^{48}$ it is Congress that decides whether to create lower federal courts, how to arrange them, how many judges will be appointed to them, and whether to abolish them..$^{49}$ Congress also has the power to grant jurisdiction to ${ }^{50}$ and withdraw jurisdiction from, ${ }^{51}$ lower federal courts. ${ }^{52}$ Moreover, although judges have the power to issue final judgments, they must rely on the executive for enforcement. ${ }^{53}$

possess the means to protect their institutional integrity against unconstitutional political branch encroachments").

${ }^{47}$ Geyh, supra note 7, at 163 ("The judiciary's institutional independence is, therefore, more closely circumscribed by accountability-promoting mechanisms for congressional control of the judiciary's budget, structure, administration and jurisdiction.”).

${ }^{48}$ U.S. CONST. art. III, $\S 1$ ("The judicial Power of the United States, shall be vested in one supreme Court, and in such inferior Courts as the Congress may from time to time ordain and establish.").

49 Ferejohn, supra note 26, at 359 ("The Constitution gives Congress the authority to create (or not create) federal courts other than the Supreme Court, to create and regulate their jurisdictions, to decide how many federal judges there will be ....."). Congress famously used its power over the structure and existence of the courts to repeal the Judiciary Act of 1801, including eliminating judgeships. Jackson, supra note 10, at 991 ("Yet after the Jeffersonians' ascent to power, in 1802 Congress enacted a statute to repeal legislation from the closing days of the Adams Administration that had created several new judgeships (filled with Federalist appointees); it thus effectively abolished Article III judgeships.").

50 Jackson, supra note 10, at 992 ("[Congress] has broad powers to control the jurisdiction of the federal courts ...."); Ferejohn \& Kramer, supra note 10, at 986 ("[E]ven the most aggressive readings of Article III recognize that Congress has wide latitude to regulate the business of the federal courts.").

${ }^{51}$ Ferejohn \& Kramer, supra note 10, at 988 ("Congress routinely dispossesses federal courts of authority to hear cases or award remedies because of concern for how the judges might rule, or in order to circumscribe their ability to interfere with congressional objectives."). Moreover, in limited circumstances, Congress can also cut the courts out of the decision to imprison by suspending the privilege of the writ of habeas corpus. U.S. CONST. art. I, $\S 9$ ("The Privilege of the Writ of Habeas Corpus shall not be suspended, unless when in Cases of Rebellion or Invasion the public Safety may require it.”).

${ }^{52}$ Whether Congress can withdraw jurisdiction without limit is another question, and one that is the subject of this Article. See Henry P. Monaghan, Jurisdiction Stripping Circa 2020: What The Dialogue (Still) Has to Teach Us, 69 DuKE L.J. 1, 29 (2019) ("[T]he Court a coordinate branch of the national government - will excise subject-matter limitations on its appellate jurisdiction when a substantial, undefended purpose of such jurisdiction-stripping legislation is to limit the Court's ability to consider a properly preserved constitutional claim.”). Cf. Ex parte McCardle, 74 U.S. (7 Wall.) 506, 514 (1868) (holding that the Court will not look for Congress's motivation when it withdraws jurisdiction).

53 Benjamin Ginsberg, Presidential Government 285 (2016) (noting that federal courts generally must turn to executive agencies or the President to enforce judgments); see also Burbank, supra note 6, at 323-24 (noting that the President has only rarely refused to execute federal court judgments). 
While Congress may not diminish the salaries of sitting federal judges, it can increase their workload by failing to appoint new judges to overloaded courts $^{54}$ and by cutting funding for court clerks, court security, and information technology. ${ }^{55}$ Conversely, Congress can reduce the influence of Article III courts by creating other institutions with the power to interpret federal law, like administrative agencies and legislative courts, and vesting them with authority to resolve vast numbers of legal disputes that otherwise would fall to Article III courts. ${ }^{56}$

Perhaps most fundamentally, federal courts are dependent on Congress for providing them the law to apply. ${ }^{57}$ Courts are constrained not only by substan-

54 Alicia Bannon, Brennan Ctr. Just., The ImPACT OF Judicial VACANCIES ON FEDERAL TRIAL COURTS, 1-2 (2014), https://www.brennancenter.org/sites/default/files/publications/Im pact\%20of\%20Judicial\%20Vacancies\%20072114.pdf [https://perma.cc/X36K-AAHG] (arguing that sustained vacancies in federal trial courts leads to judicial burn-out, delays, less time spent on each case, and increased administrative burdens).

${ }^{55}$ Ferejohn \& Kramer, supra note 10, at 985 ("Judges must worry about funds to keep this machine running and, especially, to hire capable staff and supply them with adequate resources (which include computer and research support, courthouse security, storage facilities, press offices, and much more)."); see also JOHN G. ROBERTS, 2013 YEAR-END REPORT ON THE FEDERAL JUDICIARY 5-6, https://www.supremecourt.gov/publicinfo/year-end/2013ye ar-endreport.pdf [https://perma.cc/J3MQ-8LWC] (noting that sequestration of funds had a deleterious effect on the administration of the federal courts, including leading to fewer public defenders, decreasing court security, and delaying trials).

${ }^{56}$ Ferejohn \& Kramer, supra note 10, at 989 ("[F]ederal lawmakers have constituted a variety of non-Article III tribunals-so-called legislative or Article I courts - to adjudicate federal claims and interpret and apply federal law."). For example, the United States Court of Federal Claims, a legislative court, shares jurisdiction with the district courts over suits for money against the government. 28 U.S.C. $\S 1491(a)-(b)$. Bankruptcy Courts, also legislative courts, hear suits that otherwise fall within the jurisdiction of district courts. 28 U.S.C. $\$ \S 151,1334$ (the former creating bankruptcy courts within district courts and the latter granting jurisdiction to district courts).

57 See PfANDER, supra note 18, at 405 (noting that applying rules of decision is precisely what courts do). 
tive law, ${ }^{58}$ but also the evidentiary ${ }^{59}$ and procedura $^{60}$ rules that Congress writes. $^{61}$

Considering the differences between decisional independence and institutional independence, scholars largely have concluded that judicial independence means something very different in the context of individual judges than it does for the judiciary as an institution. As Professors Ferejohn and Kramer put it, the federal system "protects individual judges from direct outside interference while making the institution in which they work vulnerable to control by the political branches of government." 62

Although the dichotomy between decisional and institutional independence is a useful heuristic, the line separating these concepts "often blurs in application," as Professor Geyh has noted. ${ }^{63}$ In this view, incursions on the courts' institutional independence can have ripple effects on the decisional independence of individual judges. For example, if Congress threatens to withdraw jurisdiction from the federal courts over a politically sensitive subject matter, then individual judges may be inclined, in a particular case, to reach a conclusion that protects the judiciary as an institution. Indeed, research suggests that the Supreme Court does voluntarily diminish its own power in response to threats of "Court-curbing" legislation, that is, "legislative attempts to limit or remove the Supreme Court's power." ${ }^{4}$

58 Pamela S. Karlan, Judicial Independences, 95 GEO. L.J. 1041, 1049 (2007) (“[T]he job of the courts is to vindicate the statutory scheme enacted by the legislature."); Zoldan, Klein, supra note 20, at 2150 ("As a number of scholars have recognized, writing rules of decision for courts to follow - that is, writing the substantive law-is precisely what a legislature does.").

59 Zoldan, Klein, supra note 20, at 2150 ("Congress can, and does, write rules of evidence, defining what is relevant, what is admissible and inadmissible, and who is competent to give testimony."); see also Act of Jan. 2, 1975, Pub. L. 93-595, 88 Stat. 1926 (establishing and enacting the Federal Rules of Evidence).

${ }^{60}$ E.g., 28 U.S.C. $\S 1651$ (authorizing federal courts to issue writs); 28 U.S.C. $\S 1696$ (providing for service of process in foreign and international litigation); 28 U.S.C. $\S 1713$ (providing rules for class actions); 28 U.S.C. $§ 1863$ (establishing standards for jury selection); 28 U.S.C. $\S 1914$ (setting out district court filing fees).

${ }^{61}$ Although Congress does create evidentiary and procedural rules itself, it also can, and does, delegate authority to the courts to write them. 28 U.S.C. $\$ 2072$.

${ }^{62}$ Ferejohn \& Kramer, supra note 10, at 964; see also Geyh, supra note 7, at 163 ("The net effect . . . is a system of (more or less) independent judges, superimposed on a (more or less) dependent judiciary."). On the historical origins of the distinction between decisional and institutional independence, see Jack N. Rakove, The Original Justifications for Judicial Independence, 95 GEO. L.J. 1061, 1063 (2007) ("Securing the independence of individual judges, however, did not mean that the judiciary had become a separate department of government.").

${ }^{63}$ Charles Gardner Geyh, Judicial Independence as an Organizing Principle, 10 AnN. REv. L. \& SOC. SCI. 185, 192 (2014).

${ }^{64}$ CLARK, supra note 21 , at 25. 


\section{The Core of Judicial Independence}

Considering the imperfect way that the judiciary is protected from political influence, some scholars have concluded that the independence of the judiciary is more mythical than real ${ }^{65}$ Nevertheless, there is also a long scholarly tradition of searching for the core of judicial independence-that is - some function of the judiciary that the political branches may not lawfully invade. ${ }^{66}$ After describing the parameters of the debate, I offer and defend a vision of the core of judicial independence.

\section{a. Competing Visions of the Core of Judicial Independence}

Professor Burbank argues that "the core of federal judicial independence is freedom of judicial decisions from control by the executive or legislative branches." 67 While acknowledging that "control" is an indeterminate concept, Burbank notes that the range of debate over the core of judicial independence is quite narrow. ${ }^{68}$ As he notes, it is widely accepted that Congress lacks the power to reopen final judgments. ${ }^{69}$ Moreover, it is also widely accepted that Congress has the power to change the law prospectively. ${ }^{70}$ As a result, he argues, the debate over the core of the judiciary's independence should be limited to "(1) the judicial power to interpret and implement the Constitution, and (2) the irreducible powers of federal courts to act as such." 71

Much of the current debate over the core of judicial independence takes place in the range that Burbank sets out, focusing on the scope of Congress's power to withdraw jurisdiction from the federal courts under the Constitution's

${ }^{65}$ See, e.g., Martin H. Redish, Federal Judicial Independence: Constitutional and Political Perspectives, 46 MERCER L. REV. 697, 700, 702-03 (1995) (arguing that judicial independence is limited to good behavior and compensation clauses).

66 See, e.g., Geyh \& Van Tassel, supra note 12, at 86 ("The Framers neither considered nor guarded against other, more speculative political branch encroachments upon the judiciary's institutional autonomy ...."). For an assessment of the relationship between de jure and de facto judicial independence, see James Melton \& Tom Ginsburg, Does De Jure Judicial Independence Really Matter?, J.L. \& CTS., Fall 2014, at 187, 190 ("Judicial independence is a complex and contested concept, but at its core, it involves the ability and willingness of courts to decide cases in light of the law without undue regard to the views of other government actors.").

${ }^{67}$ Burbank, supra note 6, at 331.

${ }^{68} I d$. at 335.

${ }^{69}$ Id . at 325 (citing Plaut v. Spendthrift Farms, Inc., 514 U.S. 211 (1995), for the proposition that Congress cannot reopen final judgments).

${ }^{70}$ Id. (citing The Federalist No. 81, at 484 (Alexander Hamilton) (Clinton Rossiter ed., 1961) ("A legislature ... may prescribe a new rule for future cases.”)); see also Zoldan, Klein, supra note 20, at 2150 ("[W]riting rules of decision for courts to follow-that is, writing the substantive law - is precisely what a legislature does.").

${ }^{71}$ Burbank, supra note 6, at 325-26. 
Exceptions Clause. ${ }^{72}$ Ex Parte McCardle ${ }^{73}$ can be taken to stand for the proposition that Congress's Exceptions Clause power is nearly unlimited, even if the result is to direct a federal court to reach a particular conclusion in a pending case. ${ }^{74}$ However, Professor Monaghan reads the Exceptions Clause more narrowly, arguing that Congress may run afoul of Article III by withdrawing federal court jurisdiction for the purpose of defeating judicial review of constitutional claims. He predicts that "the Court-a coordinate branch of the national government-will excise subject-matter limitations on its appellate jurisdiction when a substantial, undefended purpose of such jurisdiction-stripping legislation is to limit the Court's ability to consider a properly preserved constitutional claim." 75 Importantly, Monaghan stops short of extending this prediction to statutory claims. Instead, he suggests that Congress might be justified in upholding a statute that strips jurisdiction when no constitutional rights are at stake. ${ }^{76}$

Other scholars have read the Exceptions Clause either more broadly or more narrowly than Monaghan. Some have argued that Congress may not enact a statute that tells the federal courts how to rule in a particular case, even in the context of purely statutory claims. ${ }^{77}$ By contrast, a number of scholars view Congress's power under the Exceptions Clause more broadly. Professor Sprigman argues that Congress may strip jurisdiction from the federal courts even over claims asserting violations of the Constitution..$^{78}$ In this way, Sprigman concludes, Congress may "displace a judicial interpretation of the Constitution's meaning with its own."79 Professor Grove makes the related point that, unlike some incursions on judicial independence, there is not a broad political

${ }^{72}$ Krotoszynski \& DeProspo, supra note 22 (arguing for a broad rendering of a principle that prevents Congress from directing federal courts to reach particular judgments in pending cases); Evan H. Caminker, Schiavo and Klein, 22 Const. Comment. 529, 542-43 (2005) (arguing that Congress has the constitutional power to direct a federal court decision provided that it is framed in a particular way); see also Howard M. Wasserman, The Irrepressible Myth of Klein, 79 U. CiN. L. REv. 53, 53-56 (2010).

${ }^{73}$ Ex Parte McCardle, 74 U.S. (7 Wall.) 506, 514 (1868) (holding that the Court will not consider Congress's motivation when it withdraws jurisdiction).

${ }^{74}$ Zoldan, Klein, supra note 20, at 2159 n.159 (describing the tension between McCardle and a principle that Congress may not direct a federal court to reach a particular decision in a pending case).

75 Monaghan, supra note 52, at 29.

${ }^{76} \mathrm{Id}$. at 67 (noting that jurisdiction stripping in the statutory context presents different issues than in the constitutional context and "[p]erhaps ... should be upheld").

77 E.g., Krotoszynski \& DeProspo, supra note 22 (arguing for a broad rendering of a principle that prevents Congress from directing federal courts to reach particular judgments in pending cases).

${ }^{78}$ Sprigman, supra note 22 (arguing for broad congressional power under the Exceptions Clause).

${ }^{79}$ Id. 
consensus against jurisdiction-stripping. ${ }^{80}$ She concludes that attempts by the political branches to strip the federal courts of jurisdiction, even over constitutional questions, may be met with little popular resistance, even if the political process presents additional barriers. ${ }^{81}$

\section{b. A Proposed Core of Judicial Independence}

I propose that the core of judicial independence is the authority of the federal courts to adjudicate specific legal disputes that have been presented to them free from legislative direction. In this proposal, Congress has broad authority to set policy by writing rules of decision for courts to follow. However, the court should not apply a change in law to a pending case when Congress has failed to address a governmental objective other than merely resolving pending cases. ${ }^{82}$ Moreover, the courts must apply a generally applicable law, but not a law that creates special exemptions for a closed class of identifiable individuals. ${ }^{83}$ In addition, Congress may withdraw jurisdiction over a class of cases, even if some of those cases are pending. But, the court should not give effect to a withdrawal of jurisdiction if the only result is the termination of pending cases.$^{84}$ Finally, Congress has wide latitude to assert the government's sovereign immunity. However, a court should not recognize an assertion of sovereign immunity that is better characterized as governmental self-dealing..$^{85}$

My proposed formulation is largely within the range of debate over the core of judicial independence articulated by Professor Burbank. In a sense, my formulation can be considered a gloss on Burbank's proposition that the federal courts must have the irreducible power to act as federal courts. My formulation complements the proposal offered by Professor Monaghan; but, it is perhaps more protective of judicial independence because it suggests a limitation on Congress's power over the jurisdiction of the courts in both statutory and con-

${ }^{80}$ Grove, supra note 22 , at 471,518 (noting that there is no bipartisan norm that jurisdictionstripping is "off the wall").

${ }^{81} I d$. at 523 (noting that modern attempts at jurisdiction stripping have been unsuccessful); see also Tara Leigh Grove, The Structural Safeguards of Federal Jurisdiction, 124 HARV. L. REV. 869, 870-74, 886 (2011) (describing how political actors have used normal legislative processes to block jurisdiction-stripping measures). A number of scholars have argued for a narrow, but more definite, core of judicial independence centered around the court's practices and procedures. See, e.g., Linda S. Mullenix, Unconstitutional Rulemaking: The Civil Justice Reform Act and Separation of Powers, 77 MinN. L. REv. 1283, 1322 (1993) ("[T]he theory of inherent court power nonetheless requires that congressional involvement in rulemaking acknowledge the 'significance of a certain degree of judicial autonomy' over internal court rules of practice and procedure."); Paul D. Carrington, A New Confederacy? Disunionism in the Federal Courts, 45 DukE L.J. 929, 972-73 (1996) (“[T]here is a core of control vested in the Supreme Court that is beyond the constitutional reach of Congress.").

82 See infra Section III.A.

${ }^{83}$ See infra Section III.B.

${ }^{84}$ See infra Section III.C.

${ }^{85}$ See infra Section III.D. 
stitutional cases. Moreover, my proposal, unlike Monaghan's, does not turn on finding an illicit motive on the part of Congress. Similarly, my conception of the core of judicial independence is more protective of the judiciary than the vision advanced by Professor Sprigman. Sprigman does not distinguish between Congress's power over general policy matters and matters affecting identifiable individuals; in my view, by contrast, Congress should have less leeway to legislate for an identifiable individual than it does for a class of indeterminate membership. ${ }^{86}$ As described below, there are normative, structural, and doctrinal justifications for preserving the core of judicial independence as I have described it.

First, allowing the courts to adjudicate specific legal disputes that have been presented to them without legislative direction vindicates persuasive normative views about the goals of an independent judiciary. Elaborating on the values protected by judicial independence, Professor Ferejohn argues that it protects the "rule of law," by which he means "making sure that powerful people-particularly elected officials - cannot manipulate legal proceedings to their advantage." ${ }^{87}$ In addition, without judicial independence, he argues, government officials "may interfere in the enforcement of statutes enacted by previous legislatures without bothering to go through procedural formalities." 88 Preserving the core of judicial independence as I describe it-that is, the courts' ability to actually decide cases pending before them-protects the values identified by Professor Ferejohn. If courts retain the power to decide cases pending before them, then they can ignore elected officials' attempts to manipulate legal proceedings to reach a result that favors them in a particular pending case. Moreover, if courts have the power to decide pending cases, then they can prevent Congress from effectively changing the substantive law in particular cases in the guise of altering jurisdictional rules.

The values that Professor Ferejohn describes are similar to an argument in The Dialogue, Professor Henry Hart's foundational essay on federal court jurisdiction. ${ }^{89}$ In The Dialogue, one of Hart's speakers argues that Article III can be read to create a space for a federal court not just to declare one party to a case the winner, but actually, acting like a court, to decide the case. In his words, "if Congress directs an Article III court to decide a case, I can easily read into Article III a limitation on the power of Congress to tell the court how to decide it." ${ }^{90}$ Protecting the core of judicial independence, as I define it, supports the value identified in Hart's Dialogue. Preventing Congress from directing a court to pick the winner and loser in a particular pending case preserves

86 See infra Sections III.A-B.

${ }^{87}$ Ferejohn, supra note 26, at 366.

${ }^{88} I d$. at 367.

${ }^{89}$ Henry M. Hart, Jr., The Power of Congress to Limit the Jurisdiction of Federal Courts: An Exercise in Dialectic, 66 HARV. L. REV. 1362, 1372-73 (1953).

${ }^{90} \mathrm{Id}$. at 1373. 
the court's ability to act like a court, including its power to make factual findings and draw legal conclusions that bear on the outcome of the case. ${ }^{91}$ Moreover, insulating a court's ability to adjudicate particular, pending cases allows the court to proceed according to known procedural rules, a valued characteristic of courts. ${ }^{92}$ Conversely, if Congress could interfere in a pending case to direct the court to declare one litigant a winner, the court's normal procedural rules, findings of fact, and legal conclusions are all made irrelevant to the judgment it renders.

Framed another way, the courts' ability to decide cases pending before them can be considered the core of judicial independence because it protects values associated with both institutional and decisional independence. ${ }^{93}$ Preserving the case-adjudicating function of the courts protects the judiciary's institutional independence by placing a limit on Congress's otherwise unlimited power to arrange federal court jurisdiction under the Exceptions Clause. Allowing courts to disregard some congressional limits on their jurisdiction in pending cases secures for them a measure of freedom from political interference. ${ }^{94}$

Perhaps less obviously, preventing Congress from directing the result in pending cases also protects the decisional independence of individual judges. When Congress threatens to withdraw jurisdiction from the courts in a way that would terminate pending cases, the judges considering those cases are made acutely aware of the political salience of their pending decisions. It is likely that a judge who knows a case on her docket has been targeted by Congress will feel pressure to rule in a way that comports with the threatened jurisdictional tinkering. This kind of outside political pressure, whether effective or not in any given case, compromises the value of decisional independence, which requires freedom from "outside pressure: personal, economic, or political." 95

Second, preserving the courts' ability to decide cases pending before them is consistent with the Supreme Court's treatment of the political branches' at-

${ }^{91}$ Caleb Nelson, Adjudication in the Political Branches, 107 Colum. L. Rev. 559, 563 (2007) ("[T]he sort of finality that is typically associated with judicial decisions" includes the powers "to make factual findings that courts are bound to accept in subsequent litigation, or to resolve legal disputes.”).

92 See Mullenix, supra note 81, at 1322 ("[T] he theory of inherent court power nonetheless requires that congressional involvement in rulemaking acknowledge the "significance of a certain degree of judicial autonomy' over internal court rules of practice and procedure.").

${ }^{93}$ Geyh, supra note 63, at 185, 192 (noting the potential overlap between institutional and decisional independence). A special thanks to Charles Geyh and Henry Monaghan for suggesting this line of inquiry.

${ }_{94}$ Burbank, supra note 6, at 320 (arguing that the standard view of judicial independence assures that "judges free of congressional and executive control will be in a position to determine whether the assertion of power against the citizen is consistent with law").

95 Ferejohn \& Kramer, supra note 10, at 965 (defining decisional independence as "judges' ability to adjudicate facts and interpret law in particular cases 'free from any outside pressure: personal, economic, or political, including any fear of reprisal'"); see also Ferejohn, supra note 26 , at 355 . 
tempts to control judicial outcomes after judgment. Hayburn's Case has long stood for the proposition that a statute may not constitutionally vest authority in the judiciary to enter judgment if that judgment can later be revised by executive action. ${ }^{96}$ Analogously, in Plaut v. Spendthrift Farm, the Court clarified that Congress may not direct a federal court to reopen judgments that have already been finalized. ${ }^{97}$

A parallel can be drawn between the Court's prohibition on political interference with final judgments and my proposal for a prohibition on legislative direction of judicial outcomes before judgment. ${ }^{98}$ Whether before or after judgment, political interference can deprive the court of its power to actually decide a case, as Hart explained.$^{99}$ In both circumstances, the judicial process is mooted by political considerations and the court's law-application process is disconnected from the result: in short, political interference, whether before or after judgment, makes the court all-but-superfluous to a case's outcome.

Indeed, in one respect, the comparison between pre- and post-judgment political interference suggests that the Court should be more suspicious of prejudgment interference. When the executive revises, or Congress reopens, a federal court judgment, at least it is clear that the court's judgment and the political reaction to it are two different events. From a political accountability perspective, then, the public could reward or punish political actors for whatever position they took on the court's underlying decision. By contrast, when Congress directs courts to enter judgment for one of the parties in a pending case, the public cannot know how the case would have come out in the absence of the political interference. As a result, the electorate cannot know whether the result is purely a function of a political act, or instead, whether the court would have reached the same result in the absence of political interference. ${ }^{100}$

96 Hayburn's Case, 2 U.S. (2 Dall.) 409, 410 (1792) (holding that "revision and control" of federal court judgments by the executive is inconsistent with judicial independence). More clearly, the Court has held that constitutional courts may "render no judgments not binding and conclusive on the parties and none that are subject to later review or alteration by administrative action." Chi. \& S. Airline v. Waterman S.S. Corp., 333 U.S. 103, 113-14 (1948).

97 Plaut v. Spendthrift Farm, Inc., 514 U.S. 211, 227 (1995) (holding that Congress may not require the federal courts to reopen final judgments). $C f$. Miller v. French, 530 U.S. 327, 346-47 (2000) (upholding a statute that revised final judgments, temporarily, for the purpose of facilitating other changes that were the main purpose of the law).

98 Gordon G. Young, Congressional Regulation of Federal Courts' Jurisdiction and Processes: United States v. Klein Revisited, 1981 WIS. L. Rev. 1189, 1243-44 (1981) (arguing that Klein represents an extension of the principle against nonjudicial revision of court judgments).

99 See Hart, supra note 89 at 1373 ("[I]f Congress directs an Article III court to decide a case, I can easily read into Article III a limitation on the power of Congress to tell the court how to decide it.").

100 See Martin H. Redish \& Christopher R. Pudelski, Legislative Deception, Separation of Powers, and the Democratic Process: Harnessing the Political Theory of United States v. Klein, 100 Nw. U.L. REV. 437, 438-40 (2006) (arguing that Klein can be read to require the judiciary to prevent Congress from deceiving the electorate). I do not make the broader 
Third, formulating the core of judicial independence as the power of courts to actually decide cases pending before them without legislative direction gives modern meaning to the Reconstruction-era case of United States v. Klein, the Supreme Court's first-and as it turns out its last-strong statement defending a court's power to actually decide pending cases. ${ }^{101}$ In Klein, the Supreme Court invalidated a statute that withdrew jurisdiction from the federal courts in a group of pending cases, holding that it violated the principle of separation of powers. Specifically, the Court held that Congress unconstitutionally encroached on the judicial power because its withdrawal of jurisdiction was "founded solely on the application of a rule of decision, in causes pending, prescribed by Congress." 102

The Klein "rule of decision" principle, as this curious statement is called, has intrigued scholars for generations, ${ }^{103}$ but there has been little agreement about exactly what, if anything, Klein prohibits. ${ }^{104}$ Despite disagreement about its contours, ${ }^{105}$ Klein is the strongest doctrinal source for my definition of the

claim that the public actually would tend to be aware of decisions of the courts or the political branches.

101 United States v. Klein, 80 U.S. (13 Wall.) 128, 146 (1871) (invalidating statute that withdrew jurisdiction "founded solely on the application of a rule of decision, in causes pending, prescribed by Congress").

102 Id. at $146-47$.

103 Some scholars have searched for a principle that is largely consistent with not only Klein but also other rule of decision principle cases. Zoldan, Klein, supra note 20, at 2194-208 (arguing that Klein reflects a principle against government self-dealing); Young, supra note 98, at 1244 (arguing that Klein represents an extension of the principle against nonjudicial revision of court judgments). Others suggest that Klein is a reminder of important but unenforceable constitutional values. Caminker, supra note 72, at 542-43 (arguing that Klein is a rule of "drafting etiquette" that does not actually prevent Congress from directing a decision, only phrasing its direction in a particular way); see also Wasserman, supra note 72 , at 85 ("Klein does no more than Marbury and dozens of cases in which the Court has struck down substantive federal statutory law as violating individual constitution rights."). Still others suggest that Klein stands for no coherent principle about the line between the legislature and the judiciary and should be ignored. Adrian Vermeule, The Judicial Power in the State (and Federal) Courts, 2000 SuP. CT. REV. 357, 380-81.

${ }^{104}$ Klein is so vexing because it seems both intuitively correct and literally false. On one hand, by preventing Congress from dictating a rule of decision in a pending case, Klein preserves judicial independence by creating space for the courts actually to decide cases pending before them. On the other hand, Klein seems to conflict with longstanding precedent that requires courts to apply the law as Congress writes it, even if that means applying a newly enacted law to a case on appeal from a final judgment. United States v. Schooner Peggy, 5 U.S. (1 Cranch) 103, 109-10 (1801) ("[When] subsequent to the judgment, and before the decision of the appellate court, a law intervenes and positively changes the rule which governs, the law must be obeyed ....").

105 There are many possible things wrong with the statute invalidated in Klein. These have been identified by other scholars and I have explained and questioned them in previous work. These include: the fact that Congress provided a rule of decision for the court to follow, the specificity of the statute, the retroactivity of the statute, the political motivation underlying the statute, the fact that the statute may have required the Court to reach an other- 
core of judicial independence because it suggests that, at least in some circumstances, Congress may not intercede in a pending federal case without violating the Constitution. As a result, the core of the institutional independence of the judiciary, as a doctrinal matter, rests on the viability of some formulation of Klein. In the rest of this Part, I describe the Klein case and explain how the modern Supreme Court has chipped away at its meaning, and along with it, the core of judicial independence.

\section{B. The Vanishing Core of Judicial Independence}

Because Klein's holding resists easy generalization into a broader principle, recounting the unusual posture of the case helps clarify its possible reach. After describing Klein, I will demonstrate how its rule of decision principle, along with the core of judicial independence, has been eroded.

\section{Klein's Rule of Decision Principle}

Klein arose out of a Civil War-era statute that permitted federal agents to seize and sell abandoned or captured civilian property confiscated in areas rebelling against the United States. ${ }^{106}$ In order to facilitate the recovery of damages by loyal residents of rebellious areas, Congress permitted claimants to bring suit against the United States for the value of confiscated property so long as the claimant demonstrated that he had "never given any aid or comfort to the present rebellion." ${ }^{107}$ In United States v. Padelford, the Supreme Court interpreted the compensation statute broadly, holding that even a person who had committed a disloyal act would be eligible to recover the value of his property so long as he later took an oath of loyalty pursuant to a presidential pardon. ${ }^{108}$

In a scenario similar to Padelford, a man named Wilson, whose property was confiscated and sold by the Union, took an oath of loyalty. ${ }^{109}$ After Wilson's death, Klein, the executor of his estate, relied on this oath and Padelford's broad reading of the compensation statute to prevail in a suit against the United States. ${ }^{110}$ While Klein's case was pending on the government's appeal, Congress passed an appropriations bill funding judgments rendered against the United States by the Court of Claims. ${ }^{111}$ The appropriations bill, however, also

wise unconstitutional result, and the fact that it inured to the benefit of the government. Zoldan, Klein, supra note 20, at 2150.

106 Abandoned and Captured Property Act of 1863, ch. 120, § 1, 12 Stat. 820, 820.

107 Id. § 3 .

108 United States v. Padelford, 76 U.S. (9 Wall.) 531, 543 (1869) (broadly interpreting the Abandoned and Captured Property Act).

109 Amanda L. Tyler, The Story of Klein: The Scope of Congress's Authority to Shape the Jurisdiction of the Federal Courts, in FEDERAL COURTS STORIES 87, 91-92 (Vicki C. Jackson \& Judith Resnik eds., 2010).

110 Id. at 92-94.

111 Act of July 12, 1870, ch. 251, § 1, 16 Stat. 230, 235. 
contained a proviso that specifically disallowed proof of a loyalty oath to serve as the basis for recovering the value of confiscated property. ${ }^{112}$ Instead, the proviso made evidence that a person took a loyalty oath pursuant to a presidential pardon conclusive proof of disloyalty, directed the trial court to dismiss these claims, and withdrew jurisdiction from the Supreme Court over claims in which the claimant had previously prevailed based on evidence of a loyalty oath. ${ }^{113}$

In Klein, the Supreme Court invalidated the proviso because its withdrawal of jurisdiction was "founded solely on the application of a rule of decision, in causes pending, prescribed by Congress." 114 Because of the opacity of this language, and the Court's refusal to strike down any other statutes under Klein, the contours of the rule of decision principle have remained somewhat of a mystery. Although the Court has not relied on the Klein rule of decision principle to invalidate any other statute, it has made offhanded references to the case a few times, suggesting the viability of some principle rooted in the case. ${ }^{115}$ In the absence of concrete Supreme Court guidance, theories about the health and scope of Klein have flourished.

\section{The Evisceration of Klein}

It was only in the modern era that the Court explicitly began to chip away at the rule of decision principle by slowly conforming it to the earlier case of Schooner Peggy. ${ }^{116}$ In Schooner Peggy, the Court upheld the application of a newly enacted law on appeal, even though the trial court correctly applied the old law at the trial stage. The Court held that, when "subsequent to the judgment and before the decision of the appellate court, a law intervenes and positively changes the rule which governs, the [new] law must be obeyed ...."117 This requirement is often referred to as the "Changed Law Rule." 118

Klein (which post-dates Schooner Peggy) can be read as an exception to the Changed Law Rule, preventing the application of new law to pending cases in certain circumstances. Read in this way, the Klein rule of decision principle and the Changed Law Rule can coexist, neither swallowing the other, so long

112 Tyler, supra note 109, at 93-94.

113 Id. at 94.

114 United States v. Klein, 80 U.S. (13 Wall.) 128, 146 (1871).

115 United States v. Sioux Nation of Indians, 448 U.S. 371, $403-05$ (1980) (mentioning Klein); Pope v. United States, 323 U.S. 1, 8-9 (1944) (same).

116 United States v. Schooner Peggy, 5 U.S. (1 Cranch) 103, 109 (1801).

117 Id. at 110.

118 Peter Gerangelos, The Separation of Powers and Legislative InTerference in Judicial Process: Constitutional Principles AND Limitations 181-83 (2009) (referring to the Changed Law Rule); J. Richard Doidge, Note, Is Purely Retroactive Legislation Limited by the Separation of Powers?: Rethinking United States v. Klein, 79 CORNELL L. REv. 910, 959-60 (1994) (same). 
as the rule of decision principle is narrower than the Changed Law Rule. By many accounts, however, if the Changed Law Rule is an exception to Klein, the Changed Law Rule swallows Klein altogether. ${ }^{119}$ Professor Araiza expressed this view when describing the vitality of Klein: "if lawmaking is the power to create liability rules and the procedural structure for enforcing those rules, then overturning a statutory interpretation and amending the underlying statute both constitute lawmaking." 120 In this view, there is no space between "amending applicable law," which is permissible under Schooner Peggy, and "prescribing a rule of decision in causes pending," which is prohibited under Klein.

The modern evisceration of the rule of decision principle resulted from the inversion of the relationship between Klein and Schooner Peggy, making the Changed Law Rule an exception to the rule of decision principle rather than the other way around. The evisceration proceeded in three stages: first as a suggestion, next as dictum, and finally as a holding.

\section{a. Stage 1: The Suggestion}

In stage one, the Court suggested that Schooner Peggy's Changed Law Rule was an exception to the rule of decision principle. The statute considered in Robertson v. Seattle Audubon modified and codified an agreement between the United States Bureau of Land Management (BLM) and the state of Oregon over logging rights and the conservation of spotted owls. ${ }^{121}$ In order to help enforce the new policy, the statute, known as the Northwest Timber Compromise, provided that a group of lawsuits brought by logging and conservation groups would be dismissed so long as BLM abided by the terms of the Compromise. ${ }^{122}$ The Court upheld the district court's dismissal of the named, pending cases because the Compromise amended the statutory provisions that formed the basis for the pending suits. ${ }^{123}$ Although it did not squarely address the issue, the Court, for the first time, suggested that the Changed Law Rule was an exception to Klein, noting in passing that Congress may always amend or repeal existing law, even for the purpose of ending ongoing litigation. ${ }^{124}$

119 Bank Markazi v. Peterson, 136 S. Ct 1310, 1335 (2016) (Roberts, C.J., dissenting) (“Saying Congress 'creates new law' in one case but not another simply expresses a conclusion on that issue ...."); William D. Araiza, The Trouble with Robertson: Equal Protection, the Separation of Powers, and the Line Between Statutory Amendment and Statutory Interpretation, 48 CATH. U. L. REV. 1055, 1104-06 (1999).

120 Araiza, supra note 119, at 1079.

121 Robertson v. Seattle Audubon Soc'y, 503 U.S. 429, 432 (1992).

${ }^{122} I d$. at 439-40 (recounting the circumstances surrounding the Northwest Timber Compromise).

${ }^{123}$ Id. at 441 .

${ }^{124} I d$. ("Because we conclude that subsection (b)(6)(A) did amend applicable law, we need not consider whether this reading of Klein is correct."). 


\section{b. Stage 2: The Dictum}

Stage two of the evisceration of the rule of decision principle was the Court's assertion that the Changed Law Rule is an exception to it rather than the other way around. In Plaut, the Court invalidated legislation that reopened a class of final judgments. ${ }^{125}$ The Court did not rest on Klein, however, instead articulating a new separation-of-powers-based restriction on reopening final judgments. ${ }^{126}$ As for Klein, the Court asserted that the rule of decision principle did not apply because "its prohibition does not take hold when Congress amends applicable law." ${ }^{127}$ Because the statute in Plaut changed the substantive legal standard for the judiciary to apply, the Court noted, it changed the law within the meaning of Klein, rendering Klein inapplicable. ${ }^{128}$

\section{c. Stage 3: The Holding}

Stage three of the evisceration of the rule of decision principle was the Court's explicit reliance on the Changed Law Rule as an exception to the application of Klein. In Bank Markazi v. Peterson, ${ }^{129}$ claimants brought suit against the country of Iran for damages arising from injuries and deaths caused by state-sponsored terrorist acts. ${ }^{130}$ Although claimants were awarded judgments amounting to billions of dollars, these judgments could not be satisfied by assets located in the United States. ${ }^{131}$ The claimants filed actions, later consolidated into single case, against Bank Markazi, the Central Bank of Iran. Under generally applicable law, however, Bank Markazi, as a Central Bank, could not be reached to satisfy the existing default judgments against Iran. ${ }^{132}$ In response, Congress enacted a statute permitting claims against Iran to be satisfied by the assets of Bank Markazi. The statute explicitly named the pending case against Bank Markazi and provided that it applied to that case and none other. ${ }^{133}$

Before the Supreme Court, Bank Markazi argued that the statute violated Klein's rule of decision principle because it prescribed a rule that applied to a

125 Plaut v. Spendthrift Farm, Inc., 514 U.S. 211, 240 (1995).

${ }^{126} I d$. at 219 ("By retroactively commanding the federal courts to reopen final judgments, Congress has violated this fundamental principle [of separation of powers].").

127 Id. at 218 (internal quotation marks omitted).

$128 I d$.

129 Bank Markazi v. Peterson, 136 S. Ct. 1310 (2016).

${ }^{130} I d$. at 1319 (setting out statutory framework at issue in Bank Markazi).

${ }^{131} I d$. at 1317-18 (describing statutory barriers to execution of judgments).

${ }^{132}$ Id. at 1318 (describing that the Foreign Sovereign Immunities Act shields property of a foreign central bank from execution).

133 Iran Threat Reduction and Syria Human Rights Act of 2012, Pub. L. 112-158, § 502, 126 Stat. 1214, 1258-60 (codified as amended at 22 U.S.C. $\$ 8772$ ) (authorizing attachment of "financial assets that are identified in and the subject of proceedings in the United States District Court for the Southern District of New York in Peterson et al. v. Islamic Republic of Iran et al.”); see also 28 U.S.C. § 1611(b)(1). 
single pending case, indeed, one identified in the statute itself. ${ }^{134}$ The Court rejected the argument, holding that the statute did not violate Klein. By permitting claimants to reach assets of one entity to satisfy judgments owed by another, Congress had amended applicable law, the Court reasoned, making Klein's restrictions inapplicable. ${ }^{135}$

After Bank Markazi, it appeared that the rule of decision principle had been swallowed whole by the Changed Law Rule. As Chief Justice Roberts noted in his Bank Markazi dissent, a Changed Law Rule exception to Klein is coextensive with Klein itself: "[c]hanging the law is simply how Congress acts." 136 If this view is correct-if every statute "changes the law" within the meaning of Klein - then Klein never applies in the only circumstance in which it might apply, that is, when Congress writes new law for the court to apply to a pending case.

Bank Markazi's definitive restatement of the relationship between the Changed Law Rule and the rule of decision principle is more than a fine doctrinal point. It is a remarkable (re)statement of the relationship between the federal courts and Congress. Although the branches have never been hermetically sealed from one another ${ }^{137}$ Klein seemed to stand for the proposition that there was some core of judicial power that Congress could not (or at least would not) invade. The viability of Klein, therefore, is of the gravest consequence to the independence of the judiciary. Without a core power to decide cases pending before it, it is hard to articulate what is left of the judiciary's independence from Congress.

Bank Markazi's summary treatment of the rule of decision principle seemed to spell the end of Klein and the independence of the judiciary. But just as the restraining power of Klein has long been exaggerated, ${ }^{138}$ its death may be exaggerated as well; the Court's decision in Patchak v. Zinke ${ }^{139}$ has unsettled the issues that Bank Markazi seemed to have resolved. Patchak's fractured opinions set out competing visions of Klein and raise the possibility that the rule of decision principle (including the core of judicial independence) has some life in it yet. Part II describes Patchak, a puzzling case that can be read either as the last gasp of breath for judicial independence or, instead, as the case that breathes new life into its core.

${ }^{134}$ Bank Markazi, 136 S. Ct. at 1323 (citing Klein for proposition that statutes that prescribe a rule of decision in pending cases are unconstitutional).

${ }^{135} I d$. ("More recent decisions, however, have made it clear that Klein does not inhibit Congress from amend[ing] applicable law." (internal quotation marks omitted)).

136 Id. at 1335 (Roberts, C.J., dissenting).

137 Buckley v. Valeo, 424 U.S. 1, 121 (1976).

138 Wasserman, supra note 72, at 55 ("[Klein] contains broad language and exaggerated rhetorical flourishes, with statements of principles that cannot literally be true and often are dead wrong.").

139 Patchak v. Zinke, 138 S. Ct. 897, 901 (2018). 


\section{PATChaK: A LAST GASP OR NeW Life FOR JUdicial INDEPENDENCE?}

Patchak arose from a decision of the Department of the Interior to take into trust a tract of land known as the Bradley Property. ${ }^{140}$ Interior made this decision at the request of the Match-E-Be-Nash-She-Wish Band of Pottawatomi Indians, who desired land for building a casino. ${ }^{141}$ Patchak, who lived near the Bradley Property, challenged the legality of Interior's action under the Administrative Procedure Act. ${ }^{142}$ While Patchak's lawsuit was pending, Congress passed The Gun Lake Act, ${ }^{143}$ which identified and declared lawful the specific decision to take the Bradley Property into trust. ${ }^{144}$ Making clear Congress's intention to pick the winner in Patchak's suit against Interior, the Gun Lake Act also required the federal courts to "promptly dismiss" claims relating to the Bradley Property. ${ }^{145}$ Specifically, it provides:

NO CLAIMS.-Notwithstanding any other provision of law, an action (including an action pending in a Federal court as of the date of enactment of this Act) relating to the [Bradley Property] shall not be filed or maintained in a Federal court and shall be promptly dismissed. ${ }^{146}$

Pursuant to this statute, the district court dismissed Patchak's suit against Interior and the D.C. Circuit affirmed. ${ }^{147}$

Before the Supreme Court, Patchak argued that the Gun Lake Act violated the Klein rule of decision principle by directing federal courts to dismiss a pending case without applying new law. ${ }^{148}$ But, following the broad definition of changing the law set out in Bank Markazi, Congress did make new law: the new law requires the court to dismiss cases relating to the Bradley Property. ${ }^{149}$ After Bank Markazi, therefore, Patchak should have been an easy case. Nevertheless, no opinion garnered a majority of the Court, and the multiple concurrences and dissent highlight the fact that the Klein rule of decision principle, seemingly laid to rest in Bank Markazi, is still unsettled. In this Part, I describe the Patchak opinions and highlight the issues they raise. In Part III, I offer sug-

${ }^{140} I d$. at 902-03. For a good explanation of Patchak's potential effect on Klein's rule of decision principle, see Monaghan, supra note 52, at 19-20 (noting that Thomas's plurality opinion seems to have articulated new and broad justifications for jurisdiction stripping provisions, despite Klein).

141 Patchak, 138 S. Ct. at 903.

${ }^{142} I d$. (describing procedural posture).

${ }^{143}$ Id. at 904 (citing Gun Lake Act, Pub. L. 113-179, 128 Stat. 1913 (2014) (requiring dismissal of Patchak's claim against Interior)).

${ }^{144} I d$. (affirming Interior's decision to take the Bradley Property into trust).

$145 I d$.

${ }^{146} I d$.

147 Id.

${ }^{148}$ Id . at 908-09 (describing and rejecting argument based on Klein's rule of decision principle).

149 Id. at 908 (citing Bank Markazi for broad reading of Changed Law Rule). 
gestions about how Patchak's unsettled issues might be, and should be, resolved.

\section{A. The Plurality}

Justice Thomas wrote an opinion for a plurality of four, including Justices Breyer, Alito, and Kagan. After framing Patchak as an issue of separation of powers, Justice Thomas offered several independent reasons why the Gun Lake Act did not violate the Klein rule of decision principle. ${ }^{150}$

First, adopting Bank Markazi's broad definition of changing the law, Justice Thomas opined that Klein's restrictions apply only when Congress directs the courts to reach a result under old law, but not when Congress "changes the law." ${ }^{151}$ A jurisdiction-stripping statute like the Gun Lake Act, Thomas wrote, changes the law because it eliminates jurisdiction for cases relating to the Bradley Property. ${ }^{152}$ Whatever Klein's restrictions may be, therefore, they do not prevent Congress from withdrawing jurisdiction over cases relating to the Bradley Property. ${ }^{153}$

Second, Thomas distinguished Klein on the ground that the appropriations proviso disapproved in Klein was a "selective" jurisdiction-stripping statute. ${ }^{154}$ By contrast, he opined, the Gun Lake Act stripped jurisdiction over "every suit relating to the Bradley Property," which he characterized as a "class of cases." 155 Because a statute that strips jurisdiction over a class of cases is a lawful exercise of Congress's power to arrange the jurisdiction of the federal courts, the Gun Lake Act, too, is lawful. ${ }^{156}$

Third, Thomas addressed the fact that the Gun Lake Act seemed specially designed to reach a single pending case. Thomas expressed doubt that the constitutional line separating the legislative from the judicial branches can be based either on Congress's motives or the number of cases affected by the change in law. ${ }^{157}$ Moreover, Thomas asserted, as a factual matter, the statute did not address a single case. ${ }^{158}$ Because it required dismissal of cases "relating

150 Id. at 905.

151 Id. (interpreting the Changed Law Rule).

152 Id.

${ }^{153} I d$. ("Section 2(b) changes the law. Specifically, it strips federal courts of jurisdiction over actions 'relating to' the Bradley Property.").

${ }^{154} I d$. at 909 ("And unlike the selective jurisdiction-stripping statute in Klein, § 2(b) strips jurisdiction over every suit relating to the Bradley Property.").

${ }^{155} I d$. (emphasis added).

${ }^{156} I d$. (concluding that the Gun Lake Act strips jurisdiction in a class of cases).

${ }^{157} I d$. at 910 ("We doubt that the constitutional line separating the legislative and judicial powers turns on factors such as a court's doubts about Congress's unexpressed motives, [or] the number of 'cases [that] were pending when the provision was enacted' ...." (internal citations omitted)).

${ }^{158} I d$. 
to" the Bradley Property, it applied, at least in theory, to an open-ended class of cases. ${ }^{159}$

\section{B. Ginsburg and Sotomayor's Concurrences}

In a concurring opinion for herself and Justice Sotomayor, Justice Ginsburg steered clear of the separation of powers implications of Patchak, opining instead that it could be resolved as an issue of sovereign immunity. ${ }^{160}$ Because it withdrew jurisdiction from the federal courts to hear a suit against the United States, Ginsburg opined, the Gun Lake Act had the functional effect of asserting the government's sovereign immunity. ${ }^{161}$ And because the United States can always assert its immunity from suit, she concluded that the Gun Lake Act was valid even though it directed a federal court to dismiss a particular, pending suit. ${ }^{162}$

Justice Sotomayor wrote a limited separate concurrence, emphasizing that, had the suit been one between private parties, she would have joined the dissent, as she did in Bank Markazi. ${ }^{163}$ She concurred only because the United States was a party. In her view, the Gun Lake Act "restored" the sovereign immunity of the United States, noting, like Ginsburg, that the assertion of sovereign immunity moots any separation of powers concerns. ${ }^{164}$

\section{Breyer's Concurrence}

Justice Breyer wrote a separate concurrence in which he opined that Congress often "confirms" administrative action. Because Interior's action to take

${ }^{159} I d$. Thomas raised two other points. First, he opined that Klein didn't actually prohibit Congress from directing the federal courts to reach a particular decision in pending cases. Id. at 909. Rather, Thomas interpreted Klein to mean only that Congress could not declare that pardons are not evidence of loyalty or strip the court of jurisdiction to reach the same result. Id. Contrary to this view, Klein rested on two separate grounds for its result: one, that by providing a rule of decision for the courts to follow, "Congress has inadvertently passed the limit which separates the legislative from the judicial power;" and two, and in the alternative, that by "impairing the effect of a pardon," the proviso infringed on "the constitutional power of the Executive." United States v. Klein, 80 U.S. (13 Wall.) 128, 147 (1871). Second, Thomas also addressed the argument that Congress impermissibly interfered with the Court's previous decision in Match-E-Be-Nash-She-Wish Band of Pottawatomi Indians v. Patchak, 567 U.S. 209 (2012) (Patchak I), which held that Patchak's case "may proceed." Patchak, 138 S. Ct. at 903-04. He opined that Patchak's suit was not final, so Plaut's rule against reopening final judgments did not apply. See id. at 908.

160 Patchak, 138 S. Ct. at 912-13 (Ginsburg, J., concurring).

161 Id. at 913.

${ }^{162}$ Id. at 912-13 ("Just as it is Congress' prerogative to consent to suit, so too is it within Congress' authority to withdraw consent once given.").

${ }_{163}$ Id. at 913 (Sotomayor, J., concurring); see also Bank Markazi v. Peterson, 136 S. Ct. 1310, 1329-30 (2016) (Sotomayor, J., dissenting).

${ }^{164}$ Patchak, 138 S. Ct. at 914 (Sotomayor, J., concurring). 
the Bradley Property into trust was itself constitutional, Congress's action confirming or ratifying this administration action was likewise constitutional. ${ }^{165}$

\section{Roberts's Dissent}

Chief Justice Roberts authored a dissent joined by Justices Kennedy and Gorsuch. He would have held that Congress violates the principle of separation of powers when it "manipulates jurisdictional rules to decide the outcome of a particular pending case." 166 In a reprise of his dissenting opinion in Bank Markazi, Roberts recounted the history of the Confederation period. He emphasized the social and economic dislocations caused by early state legislatures' usurpation of judicial functions. ${ }^{167}$ But, in Patchak, the Chief Justice drew a different conclusion than he did in his Bank Markazi dissent, and it was a conclusion with potentially far-reaching consequences: the Constitution prohibits the legislature from applying the law in a particular case. ${ }^{168}$ Drawing on the general principle that the legislature sets rules for society while the judiciary and executive apply those rules in individual cases, Roberts suggested that Article III limits the legislature's power to decide individual cases. ${ }^{169}$ Roberts connected this principle with Klein, opining that Klein stands for the proposition that the legislature may not intervene in a particular pending case in a way that cuts out the role of the judiciary. ${ }^{170}$

Roberts went on to respond to the plurality and concurring opinions. First, Roberts rejected Thomas's argument that the Gun Lake Act withdrew jurisdiction over a class of cases. Rather, he opined, the Gun Lake Act was intended to withdraw jurisdiction over a particular case, despite being framed in a general way. ${ }^{171}$ The specificity, opined Roberts, distinguishes the Gun Lake Act from the statute upheld in Bank Markazi, which resolved consolidated cases from more than one thousand claimants. ${ }^{172}$

Second, Roberts countered Thomas's argument that all Congress must do to "amend applicable law" within the meaning of Klein is enact a statute. Contrary to Thomas's assertion that the Changed Law Rule is a wholesale exception to Klein, Roberts would have held that "the concept of 'changing the law'

165 Id. at 911-12 (Breyer, J., concurring).

${ }_{166}$ Id. at 919-20 (Roberts, C.J., dissenting).

167 Id. at 914-15 (noting "disarray produced by this system of legislative equity" (internal quotation marks omitted)).

${ }^{168} I d$. at 915, 919-20 ("Congress exercises the judicial power when it manipulates jurisdictional rules to decide the outcome of a particular pending case.").

169 Id at 915.

170 Id. at $915-916$.

171 Id. at 917.

172 Id. at 918 . 
must imply some measure of generality or preservation of an adjudicative role for the courts." 173

Third, the Chief Justice rejected Justices Ginsburg and Sotomayor's conclusion that the Gun Lake Act restored the government's sovereign immunity. ${ }^{174}$ Roberts did not respond directly to the constitutional argument-whether Congress may assert sovereign immunity in particular pending case - but rather rested on statutory interpretation grounds. Specifically, Roberts opined that the Gun Lake Act, in fact, failed to restore the sovereign immunity of the United States because it did not use the words like "immunity" or "consent." 175

Fourth, Roberts responded to Justice Breyer's opinion that Congress was merely confirming, without augmenting, the law. If Congress did not alter the law, responded Roberts, then it could not have "changed the law" within the meaning of the Changed Law Rule. ${ }^{176}$ More fundamentally, Roberts objected that congressional action is not necessarily constitutional merely because it ratifies or simplifies administrative action. Instead, the touchstone of constitutionality is whether Congress is exercising judicial power. ${ }^{177}$ Because the Gun Lake Act applied the law to a particular case, Roberts opined that it is unconstitutional irrespective of whether it also confirmed administrative action. ${ }^{178}$

I explain this fractured set of opinions at length to demonstrate how some fundamental issues about judicial independence are still unresolved. Indeed, Patchak's various opinions touch on many of the same themes as Hart's Dialogue, confirming both the fundamental nature of the issues Patchak raises and The Dialogue's contemporary relevance. ${ }^{179}$ The disagreements in Patchak, although couched in fine doctrinal terms, are in reality disagreements about nothing less important than the line between the judicial and legislative powers. In Part III, I explain how the fundamental issues raised in Patchak can be resolved in a way that protects the core of judicial independence while still providing ample room for Congress to legislate.

\section{A CHANCE FOR JUdicial INDEPENDENCE}

Patchak's fractured opinions broach an array of issues relating to the Klein rule of decision principle and judicial independence more generally. But, because a majority of the Court agreed on Patchak's result without agreeing on a rationale, Patchak offers little guidance on what the Court might do in a slightly different future case and even less guidance to lower courts on how to ap-

173 Id. at 920.

174 Id. at $921-22$.

175 Id. at 922.

${ }^{176} I d$.

177 Id.

$178 I d$.

179 Monaghan, supra note 52, at 4 (noting the contemporary relevance of Hart's The Dialogue). 
proach these important issues. ${ }^{180}$ In this Part, I address the issues joined, but not settled, in Patchak, including: the scope of the Changed Law Rule; the constitutionality of targeted legislation; what it means for Congress to withdraw jurisdiction over a "class of cases;" and the relationship between sovereign immunity and the rule of decision principle. After exploring the dispute over each of these issues, I suggest how the courts, including the Supreme Court, should approach them in a future case. Although there are no easy answers to the questions raised in Patchak, following the suggestions set out below will allow courts to preserve the core judicial role without encroaching on Congress's legislative function.

\section{A. The Changed Law Rule}

Patchak's plurality and dissent squarely join issue on the breadth of the Changed Law Rule. In Thomas's view, any statute changes the law sufficient to defeat an application of Klein, even a statute that makes an exception to the generally applicable law for a single piece of property. ${ }^{181}$ As Thomas crisply reasoned, by withdrawing jurisdiction over claims relating the Bradley Property, the Gun Lake Act "changes the law .... Before the Gun Lake Act, federal courts had jurisdiction to hear these actions. Now they do not." 182 Roberts, by contrast, reads a limitation into the Changed Law Rule, suggesting that not every statute "changes the law" in a way that defeats Klein. ${ }^{183}$ In a sense, this dispute is the most important one in Patchak. If Thomas is correct, then no statute ever can be invalid under the Klein rule of decision principle because the Changed Law Rule is coextensive with it. ${ }^{184}$

\section{The Overbreadth of Thomas's Approach}

Thomas's rendering of the Changed Law Rule is too broad to comport either with Klein or with Thomas's own stated justification for the Changed Law Rule. First, Thomas's Changed Law Rule is at odds with Klein itself. The ap-

${ }^{180}$ Lower courts disagree about how to apply the rule in Marks v. United States, 430 U.S. 188, 193 (1977), which provides that "[w] $[\mathrm{wen}$ a fragmented Court decides a case and no single rationale explaining the result enjoys the assent of five Justices, 'the holding of the Court may be viewed as that position taken by those Members who concurred in the judgments on the narrowest grounds ...." 'Under one approach to this test, a position is the narrowest ground when its reasoning implicitly has been approved by a majority who support the result. See King v. Palmer, 950 F.2d 771, 781 (D.C. Cir. 1991) (en banc). Under a second approach, a position is the narrowest ground for the result when it would change the law the least, or be most specific to the case being decided. See Bormuth v. Cnty. of Jackson, 849 F.3d 266, 279 (6th Cir. 2017).

181 Patchak, 138 S. Ct. at 905.

$182 I d$. (internal citation omitted).

${ }^{183}$ Id. at 920 (Roberts, C.J., dissenting) (“[T]he concept of 'changing the law' must imply some measure of generality or preservation of an adjudicative role for the courts.").

${ }^{184}$ See supra Section I.B. 
propriations proviso held unconstitutional in Klein changed the law within Thomas's definition of that concept. Recall that Klein's appropriations proviso required the court to dismiss claims that were predicated on evidence that the claimant took an oath of loyalty. ${ }^{185}$ Under Thomas's definition of the Changed Law Rule, the appropriations proviso changed the law: before the proviso, federal courts had jurisdiction to hear actions predicated on evidence of a loyalty oath. After the appropriations proviso, they did not. ${ }^{186}$ On Thomas's own reading, therefore, there is no space for a Klein principle to operate consistent with the Changed Law Rule.

Second, the vitality of Klein aside, Thomas's reading of the Changed Law Rule is too broad because it conflicts with his own description of what the principle of separation of powers requires. Thomas opined in Patchak that the principle of separation of powers prevents Congress from "usurp[ing] a court's power to interpret and apply the law to the [circumstances] before it." ${ }^{187}$ But, the Changed Law Rule as Thomas envisions it validates statutes that do just that. In Robertson, the Court (in an opinion by Thomas himself) upheld the Northwest Timber Compromise, which directed the federal courts to interpret a statute in a particular way for three pending cases. ${ }^{188}$ The Court held that this statute changed the law. ${ }^{189}$ If a statute that directs courts to interpret a statute in a particular way for a pending case changes the law in a way that defeats the application of Klein, then there would seem to be no statute that could encroach on the judicial power. ${ }^{190}$ The breadth of Thomas's approach to the Changed Law Rule warrants a search for a different approach to this principle.

\section{Three Narrower Approaches}

Justice Thomas's Changed Law Rule is inconsistent both with Klein and with even an extremely modest view of judicial independence. A narrower definition of what it means to change the law, by contrast, not only makes it possible to reconcile the Changed Law Rule and the Klein rule of decision principle but it also preserves the core of judicial independence.

185 United States v. Klein, 80 U.S. (13 Wall.) 128, 143 (1871) (describing operation of proviso).

${ }^{186}$ Cf. Patchak, 138 S. Ct. at 905, 909 ("Before the Gun Lake Act, federal courts had jurisdiction to hear these actions. Now they do not." (internal citation omitted)).

${ }^{187} I d$. at 905 (alterations in original) (internal citation omitted).

188 Robertson v. Seattle Audubon Soc'y, 503 U.S. 429, 429-30 (1992) (describing effect of Compromise).

${ }^{189}$ Id. at 438 ("We conclude that subsection (b)(6)(A) compelled changes in law ....").

190 Thomas's opinion in Patchak itself confirms this point. See Patchak, 138 S. Ct. at 908. Patchak reaffirmed Bank Markazi, which interpreted the law for one particular set of cases. Id. If the Bank Markazi statute changed the law within the meaning of the Changed Law Rule, then there is no constitutional line between law-making and law-application. 
First, the Changed Law Rule and the Klein rule of decision principle can coexist if changing the law in a way that defeats the application of Klein means setting policy. As I have argued elsewhere, ${ }^{191}$ although most statutes, no matter how modest, indisputably set policy, a statute that does little or nothing other than to decide pending cases does not set policy and should not be considered to change the law in a way that defeats the application of Klein.

Reading the Changed Law Rule to distinguish between setting policy and deciding pending cases fits neatly with constitutional law doctrine outside of the Klein context. In United States $v$. Winstar ${ }^{192}$ the government encouraged healthy banks to take over insolvent savings and loans by promising the banks favorable accounting treatment. ${ }^{193}$ These promises were made through "express arrangements between the regulators and the acquiring institutions." 194 Soon after banks merged with the insolvent institutions, Congress prohibited the government from keeping its regulatory promises, rendering many of the merged institutions instantly insolvent. ${ }^{195}$ Justice Souter, for a plurality, opined that deference to Congress's decision to invalidate the government's promises was not warranted because the statute shifted the costs of the government's breach of promise to particular parties. ${ }^{196}$ Souter noted that deference to Congress's decision to alter its obligations is appropriate only if this decision is "merely incidental to the accomplishment of a broader governmental objective." ${ }^{197}$ By contrast, if the statute appears to be doing little other than shifting the costs of governmental decisions to particular parties, the Court will not defer to the statute because it does not set policy. ${ }^{198}$ Importantly, Souter was keenly aware that the government's cost-shifting maneuver was in the public interest. ${ }^{199}$ Nevertheless, a purpose to promote the general welfare did not insulate the government from its decision to shift the costs of the government's decision to particular parties. ${ }^{200}$

The Winstar approach can be adapted easily to the Changed Law Rule. Most statutes, even quite narrow ones, set policy because they achieve a governmental objective broader than merely shifting the costs of governmental de-

191 Zoldan, Klein, supra note 20, at 2206-07 (arguing that the Changed Law Rule should be read to distinguish between statutes that set policy and statutes that do not set policy); Evan C. Zoldan, Is the Federal Judiciary Independent of Congress?, 70 StAn. L. Rev. OnLine 135, 139-40 (2018) [hereinafter Zoldan, Federal Judiciary] (same).

192 United States v. Winstar Corp., 518 U.S. 839, 839 (1996) (plurality opinion).

193 Id. at 848-51 (describing goodwill program).

${ }^{194}$ Id. at 853-54.

195 Id. at 845-48.

196 Id. at $900-03$

197 Id. at 897-98 (emphasis added).

198 Id.

199 Id. at 903.

${ }^{200} I d$. (noting that the public interest-serving aspect of the statute does not necessarily make it a public and general law). 
cisions to particular private parties. For example, a statute prohibiting or penalizing a class of conduct (say, discharging pollutants) ${ }^{201}$ would set policy within the meaning of Winstar. Although such a statute raises costs for potential polluters, it does not raise costs for particular, identifiable parties. Rather, the category of potential polluters is an indeterminate class because others might become polluters in the future and current polluters might cease polluting. As a result, this kind of statute achieves a government objective (penalizing pollution) rather than merely shifting costs to particular, identifiable polluters. By contrast, a statute that breaches a particular set of agreements (as in Winstar), or a statute that directs the result only in a particular, pending case, merely shifts costs to identifiable parties and therefore does not achieve a governmental objective other than to penalize identifiable members of a class.

Admittedly, and as Professor Araiza has noted, the Winstar approach requires some line-drawing to determine whether a very narrow statute sets policy or merely shifts costs. ${ }^{202}$ In rare cases, perhaps in a case like Patchak itself, this will be a difficult task. Because Patchak's lawsuit was prompted by a single lawsuit about a specific governmental decision and a particular piece of land, ${ }^{203}$ the Gun Lake Act can be seen as a cost-shifting measure to relieve the government of the responsibility of answering for its actions in court. Whether the Gun Lake Act did anything other than merely shift costs turns on the interpretation of the Gun Lake Act. On one hand, as Roberts suggested, ${ }^{204}$ the purpose of the statute was to require the dismissal of Patchak's claim. ${ }^{205}$ On this interpretation, the Gun Lake Act merely shifted costs for a pending case and did not set policy. ${ }^{206}$ On the other hand, in Thomas's view, the plain language of the Gun Lake Act applies to all cases, even possible future cases, relating to the Bradley Property. ${ }^{207}$ On this reading, the Gun Lake Act did set policy-the

201 E.g., 33 U.S.C. § 1311(a) (“[T]he discharge of any pollutant by any person shall be unlawful.").

202 Araiza has argued that a Winstar-inspired approach to Klein is difficult or impossible to apply as a theoretical matter. William Araiza, The Once and (Maybe) Future Klein Principle, 74 WASH. \& LEE L. REV. OnLINE 383, 394-95 (2018). While Araiza is surely correct that this test does not provide a bright-line rule to distinguish close cases, a bright-line rule may not be realistic for a complex separation of powers issue like Klein's rule of decision principle. The Winstar principle articulated here is coherent because there are cases that easily violate the principle and cases that easily survive the principle. There are cases on the line, but courts make decisions all the time that call on them to distinguish close cases.

203 Patchak v. Zinke, 138 S. Ct. 897, 897 (2018).

${ }^{204}$ Id. at 917 (Roberts, C.J., dissenting) (opining that the Gun Lake Act dictates "a particular outcome" to "a particular party").

${ }^{205}$ Gun Lake Trust Land Reaffirmation Act, Pub. L. No. 113-179, § 2(b), 128 Stat. 1913 (2014) (narrowly reaching a single pending case).

${ }^{206}$ For more on the Winstar approach to Patchak, see Zoldan, Federal Judiciary, supra note 191 at $138-40$.

207 Patchak, 138 S. Ct. at 910 ("Nothing on the face of $\S 2$ (b) is limited to Patchak's case, or even to his challenge under the Indian Reorganization Act. Instead, the text extends to all 
policy to end litigation over the Bradley Property. This interpretive dispute demonstrates that difficult issues of statutory interpretation can give rise to close cases, even under the formulation I suggest. However, because it is often easy to determine whether a statute applies to a closed class of cases or an open class, most cases will be resolved with little difficulty, making the policy / costshifting dichotomy a meaningful if not perfect distinction.

Second, and related to the policy / cost-shifting distinction drawn above, the Changed Law Rule could be read to require a court to apply a statutory change only if it changes the generally applicable law. Chief Justice Roberts made this suggestion in his Patchak dissent. ${ }^{208}$ To Roberts, a statutory change that applies to a single pending case is not a change of law that can defeat the application of Klein. The Chief Justice's suggestion hints at the possibility that targeted legislation is constitutionally suspect simply because it is targeted. There is merit to the Chief's suggestion; indeed, a constitutional principle disfavoring targeted legislation is even more robust and more complex than he suggests. The constitutional sources of a principle prohibiting targeted legislation, and questions about the scope of this principle, are discussed more fully in Section III.B., below.

Third, the ostensible conflict between the rule of decision principle and the Changed Law Rule turns out to be illusory if the original relationship between these doctrines is restored. As noted above, the evisceration of the Klein rule of decision principle was made possible by the inversion of the relationship between it and the Changed Law Rule. ${ }^{209}$ When Klein was decided, the Changed Law Rule provided that a court, even on appeal, must apply the law in force at the time it decides a case. ${ }^{210}$ Klein, which post-dated the Changed Law Rule, can be considered an exception to it, preventing the application of the Changed Law Rule when the new statute "prescribe[s] rules of decision to the Judicial Department of the government in cases pending before it." 211 Although the meaning of the this language is far from certain, it can easily be read more narrowly than the Changed Law Rule, allowing the two doctrines to coexist. For example, the Klein rule of decision principle might be read to prevent the application of new law when it purports to apply to pending cases only. This version of Klein can coexist with the Changed Law Rule because the two do not completely overlap; that is, this version of Klein will block some, but not all, appli-

suits 'relating to' the Bradley Property. Thus, § 2(b) survives even under the dissent's theory: It 'prospectively govern[s] an open-ended class of disputes' . ...").

${ }^{208}$ Id. at 920 (Roberts, C.J., dissenting) (opining that changing the law implies changing some generally applicable law).

209 See supra Section I.B.

210 United States v. Schooner Peggy, 5 U.S. (1 Cranch) 103, 109 (1801) (“[When] subsequent to the judgment and before the decision of the appellate court, a law intervenes and positively changes the rule which governs, the law must be obeyed ....").

211 United States v. Klein, 80 U.S. (13 Wall.) 128, 146 (1871). 
cations of the Changed Law Rule. ${ }^{212}$ There are other ways to narrow the rule of decision principle to make it compatible with the Changed Law Rule. ${ }^{213}$ But, at least, as this approach shows, the two need not conflict. As a result, it is possible to give meaning to the rule of decision principle and the Changed Law Rule by reading both to preserve an adjudicatory role for the courts.

\section{B. The Constitutionality of Targeted Legislation}

Klein's rule of decision principle has long been considered mysterious because its result seems both intuitively correct and inconsistent with basic principles of law. ${ }^{214}$ Chief Justice Roberts's dissent offers a possible solution to this dilemma by suggesting that Klein can be justified as an implementation of a constitutional value that prohibits legislation targeted to reach a single case. ${ }^{215}$ Roberts's suggestion is promising but requires some further elaboration.

\section{A Constitutional Value of Legislative Generality}

As Roberts correctly notes, a principle that disfavors legislation targeting an identifiable individual (often called special legislation) ${ }^{216}$ comports with other areas of constitutional law. A value disfavoring special legislation makes sense in light of Fletcher v. Peck's distinction between the legislature's lawmaking authority and the judiciary's law-application function. ${ }^{217}$ After all, if applying the law is reserved to the executive and judicial branches, then it makes sense that the legislature would be prohibited from writing a statute so specific that it can only apply to a specific individual; such a targeted statute would appear to infringe on the law-application function of the other branches. But, a value disfavoring targeted legislation is more nuanced, more robust, and even more deeply ingrained in the American constitutional fabric than Roberts suggests. As I have argued in previous work, a principle disfavoring targeted legislation - which may be called a value of legislative generality - is support-

${ }^{212}$ I will defend this reading of the Changed Law Rule below. Infra Section III.C. Importantly, Roberts's reading of the Changed Law Rule and the rule of decision principle is different than his claim that the rule of decision principle prevents Congress from intervening in a single pending case. This latter claim rests on the particularity of the statute, an issue discussed more fully below.

${ }^{213}$ For example, some scholars have suggested that it applies only to constitutional claims. E.g., Monaghan, supra note 52, at 67 (contrasting statutory claims and constitutional claims in the context of Klein).

${ }^{214}$ Zoldan, Klein, supra note 20, at 2149 (Klein's rule of decision principle seems at once "intuitively correct and too broad to be literally true").

215 Patchak v.Zinke, 138 S. Ct. 897, 915-16 (2018) (Roberts, C.J., dissenting).

216 Evan C. Zoldan, Reviving Legislative Generality, 98 MARQ. L. REV. 625, 632 (2014)

[hereinafter Zoldan, Reviving Legislative Generality] (defining special legislation).

217 See Fletcher v. Peck, 10 U.S. (6 Cranch) 87, 136 (1810) (distinguishing between lawmaking and law-application). 
ed by the Constitution's history and text, and also by persuasive normative considerations. ${ }^{218}$

First, during the Confederation period, newly independent state legislatures enacted countless targeted statutes that imposed punishment on named individuals, transferred title to land, granted individuals exemptions from the standing laws, and confiscated property from named individuals. ${ }^{219}$ By the mid-1780s, after a long decade of suffering from the repercussions of targeted legislation, the framing generation wholeheartedly repudiated their legislatures' power to enact targeted laws. ${ }^{220}$ In their writings, speeches, and debates, members of the framing generation denounced their legislatures for "extending their deliberations to the cases of individuals" and granting them unearned privileges and imposing unearned burdens on them. ${ }^{221}$ The experience of these legislative abuses served as a key impetus for a new national constitution. ${ }^{222}$

Second, and based on these experiences, the constitutional text drafted by the framers reflects a value of legislative generality. In addition to the Bill of Attainder Clauses (which most directly prohibit targeted legislative punishment), the Ex Post Facto, Contract, Equal Protection, Due Process, Takings, and General Welfare clauses also support a value of legislative generality because each can fairly be read to prohibit a certain type of particularized legislation. ${ }^{223}$ For example, although the Equal Protection Clause is primarily concerned with government classifications of individuals, ${ }^{224}$ the Supreme Court has also emphasized that the clause prohibits legislative specification by limiting the government's power to single out an individual as a "class of one." ${ }^{225}$ Simi-

218 Zoldan, Reviving Legislative Generality, supra note 216, at 650-60 (describing a constitutional principle of legislative generality); Evan C. Zoldan, The Equal Protection Component of Legislative Generality, 51 U. RicH. L. REV. 489, 489 (2017) [hereinafter Zoldan, The Equal Protection Component] (distinguishing generality from equal protection); Zoldan, Klein, supra note 20, at 2152-53 (comparing generality with the Klein rule of decision principle).

219 Zoldan, Reviving Legislative Generality, supra note 216, at 662-65 (recounting the special legislation-related abuses of the Confederation period).

${ }^{220} I d$. at 669-79 (describing the rejection of special legislation during the framing period).

221 Council of Censors, A Report of the Committee, in The Constitution of the Commonwealth of Pennsylvania 35, 38 (1784) (describing Confederation-era legislative abuses).

222 Zoldan, Reviving Legislative Generality, supra note 216, at 652. ("By the close of the confederation period, both special privileges and special detriments were considered 'repugnant to the spirit of the American republics.' It was with these experiences, and in large part driven by them, that the framers of the Constitution arrived in Philadelphia in 1787." (internal citations omitted)).

${ }^{223} I d$. at 653 (describing textual support for a value of legislative generality).

${ }^{224}$ See Engquist v. Or. Dep't of Agric., 553 U.S. 591, 601 (2008) (limiting the class-of-one doctrine).

225 Vill. of Willowbrook v. Olech, 528 U.S. 562, 564 (2000) (describing the class-of-one doctrine). For an explanation of the class of one doctrine, see Zoldan, The Equal Protection Component, supra note 218, at 525-31. 
larly, although the Due Process Clause has been applied to a wide array of government actions, one of its oldest applications prohibits the legislature from "taking the property of A and giving it to B." ${ }^{226}$ In this same way, each of the clauses identified above contains a component that reinforces legislative generality, either because of the effect given to it by the Court or the historical experiences that gave rise to its inclusion in the Constitution. Reading these clauses together suggests that a value of legislative generality pervades the Constitution and should inform its interpretation. ${ }^{227}$

Third, jurists, philosophers of law, and other commentators have long argued either that targeted legislation is outside the legislative power altogether or that it is bad law. Locke wrote that the legislature may not "rule by extemporary arbitrary decrees" 228 and its laws may not be varied "in particular cases." 229 The United States Supreme Court invoked this tradition in Hurtado v. California when it noted that "not every act, legislative in form" can be considered "law." 230 Specifically, "a special rule for a particular person or a particular case," including "acts of confiscation, acts reversing judgments, and acts directly transferring one man's estate to another," are simply excluded from its definition. ${ }^{231}$ As a normative matter, special legislation is often associated with corruption, animus, favoritism, and unjustified inequalities, ${ }^{232}$ leading commentators to conclude that it is "unjust,",233 "unfair,"234 and iniquitous. ${ }^{235}$

\section{Applying a Value of Legislative Generality}

A Klein principle that prohibits Congress from directing the result in pending cases is consistent with the constitutional value of legislative generality described above. Indeed, such a principle resonates strongly with the historical underpinnings of the Constitution: Confederation-era legislative interference

226 John V. ORTh, Due Process of LAw: A BRIEF History 52-53 (2003); see also Calder v. Bull, 3 U.S. (3 Dall.) 386, 388 (1798) (noting that impropriety of "a law that takes property from A. and gives it to B").

227 Zoldan, Reviving Legislative Generality, supra note 216, at 653 (describing the Constitution's generality clauses).

228 John Locke, Second Treatise of Government $§ 136$ (C.B. Macpherson ed., 1980) (1690).

${ }^{229}$ Id. $\S 142$.

${ }^{230}$ Hurtado v. California, 110 U.S. 516, 535 (1884).

${ }^{231}$ Id. at 535-36.

${ }^{232}$ Evan C. Zoldan, Legislative Design and the Controllable Costs of Special Legislation, 78 MD. L. REv. 415, 415 (2019) [hereinafter Zoldan, Legislative Design] (describing costs of special legislation).

${ }^{233}$ Marcus Tullius Cicero, On the Commonwealth and on the Laws 173 (James E. G. Zerzel ed., Cambridge Univ. Press 1999).

${ }^{234}$ LON L. Fuller, The Morality OF LAW 47 (12th prtg. 1980).

235 James H. Douglas, Records of the Council of Censors of the State of Vermont 67-68 (Paul S Gillies \& D. Gregory Sanford eds. 1991). 
with court judgments was a key factor precipitating the Philadelphia Convention. ${ }^{236}$ A Klein principle prohibiting Congress from directing the result in a pending case is also consistent with, if not directly compelled by, the Constitution's prohibition on certain types of special laws. And a Klein principle also resonates with the normative justifications for a value of legislative generality because legislation that targets a pending case is apt to be based on animus or favoritism..$^{237}$

There are difficult questions, to be sure, that must be answered before the Court could apply a value of legislative generality in the context of Klein. Many of these questions are raised, either explicitly or implicitly, in the exchange between Justice Thomas and the Chief Justice in Patchak. As Justice Thomas noted, at least as a formal matter, the Gun Lake Act did not apply to a single case alone. ${ }^{238}$ It was written in general language, applying to "an action pending in a Federal court" rather than to Patchak's case specifically. ${ }^{239}$ Moreover, the Gun Lake Act required the dismissal of any claim relating to the Bradley Property. ${ }^{240}$ As a result, on its face it applies to future actions relating to the Bradley Property, even if these future actions are unrelated to the suit already dismissed. ${ }^{241}$ The Chief Justice responded to these arguments by noting that the "practical operation" of the statute "unequivocally confirms that it concerns solely Patchak's suit." 242

As this exchange suggests, there are a number of difficult issues that will arise if a court seeks to apply a value of legislative generality in the Klein context. These include the following: whether a targeted statute is impermissible even if it does not name the individual case targeted; whether it is impermissible to target, not only an individual case, but also a small group of cases; and whether a statute is impermissibly targeted if some, but not all, of the targeted cases are determined at the time it is enacted.

Fortunately, the Supreme Court would not be writing on a blank slate when answering these and many other questions about the precise contours of a value of legislative generality. In previous work, I have set out the core commitments

236 Bank Markazi v. Peterson, 136 S. Ct. 1310, 1330 (2016) (Roberts, C.J., dissenting) (noting that the early state legislative abuses included interference "in cases still pending before courts, [and] granting continuances, stays of judgments," and new trials).

237 The statute upheld in Bank Markazi, for example, transferred property from an unsympathetic party (the Central Bank of Iran) to sympathetic parties (victims of state-sponsored terrorism). Iran Threat Reduction and Syria Human Rights Act of 2012, 22 U.S.C. $\$ 8772$.

${ }^{238}$ Patchak v.Zinke, 138 S. Ct. 897,910 (2018) (noting the general applicability of the Act). ${ }^{239}$ Gun Lake Trust Land Reaffirmation Act, Pub. L. No. 113-179, § 2(b), 128 Stat. 1913 (2014).

${ }^{240} I d$.

241 Patchak, 138 S. Ct. at 910. Whether Thomas is correct, or whether the Chief Justice is correct that all other claims related to the Bradley Property are barred by statutes of limitations, is a matter of statutory interpretation.

${ }^{242} I d$. at 918 (Roberts, C.J., dissenting). 
of a value of legislative generality and general principles to guide courts in peripheral cases. Succinctly stated, the value of "legislative generality disfavors legislation that singles out a person or small, identifiable group for special treatment to which the general population is not subject." ${ }^{243}$ Its core commitments, most relevant here, include prohibiting the legislature from: "interfering with both civil and criminal judicial processes for named claimants or defendants; declaring the proper interpretation of a standing law in a particular case; . . . and transferring property from one person to another." 244

Outside of these core commitments, my previous work suggests that the value of legislative generality should be less restrictive when it comes to "special laws that prefigure generally applicable laws" or "that eliminate, rather than create, disparities between people."245

In addition to this theoretical work, state courts have extensive practical experience resolving these very issues under state constitutional prohibitions on special legislation. ${ }^{246}$ To give a sense of the answers they have reached, state courts tend to hold that a statute can be prohibited as special legislation even if it does not name the individual it targets. ${ }^{247}$ Similarly, state courts sometimes invalidate a statute as impermissibly special even if it applies to a small, known group rather than a single individual. ${ }^{248}$ Finally, state courts tend to evaluate a facially general statute based on whether it applies to an "open class" or a "closed class." 249 A class is closed if it is impossible, or extremely unlikely, that another person or entity will fall within the statutory classification in the future.

${ }^{243}$ Zoldan, Reviving Legislative Generality, supra note 216, at 688.

${ }^{244}$ Id. at 688-89.

$245 I d$. at 689.

${ }^{246}$ Daniel R. Mandelker, Judith Welch Wegner, Janice C. Griffith, Evan C. Zoldan \& Cynthia Baker, State and Local Government in a Federal System 670 (9th ed. 2020) (noting that courts often invalidate statutes as special even though they do "not name a particular entity"); $i d$. at 671 ("Courts often invalidate ... narrowly drawn statutes as special laws."); $i d$. at 669 ("[C]ourts often hold that a challenged law is special when it creates a 'closed class.'”).

247 Cities Serv. Co. v. Governor of Maryland, 431 A.2d 663, 673 (Md. 1981) (“[S]tatutory provisions which did not name particular individuals or entities have been held to be prohibited special laws, whereas enactments naming specific entities have been held not to be special laws." (citations omitted)); City of Topeka v. Gillett, 4 P. 800, 804 (Kan. 1884) ("[A]n act ... may be special where it simply describes the particular persons or things so that they may be known, as well as where it gives their particular names or distinctive appellations.").

${ }^{248}$ People v. Canister, 110 P.3d 380, 385 (Colo. 2005) (statute creating class of two coconspirators violated prohibition on special legislation); Opyt's Amoco, Inc. v. Vill. of S. Holland, 568 N.E.2d 260, 269 (Ill. 1991) ("Special legislation confers a special benefit or exclusive privilege on a person or a group of persons to the exclusion of others similarly situated.").

${ }^{249}$ Canister, 110 P.3d at 384 ("By contrast, a class that is drawn so that it will never have any members other than those targeted by the legislation is illusory, and the legislation creating such a class is unconstitutional special legislation."); Sierra Club v. Dep't. of Transp., 202 P.3d 1226, 1276 (Haw. 2009) (invalidating a statute as a special law when, although framed as a general law, in reality it applied only to a closed class of one). 
Courts tend to find that a generally written statute that creates a closed class is prohibited as special legislation. ${ }^{250}$ By contrast, courts tend to uphold classifications when a statute creates an "open" class, that is, a class into which other people or entities could fall in the future. ${ }^{251}$

The Supreme Court is not, of course, required to follow the path that state courts have taken. But, the Court may find the states' doctrinal solutions useful because, for many questions about special legislation, the states have articulated relatively manageable standards. At the very least, reviewing the states' approaches will give the Court a sense of the types of issues that it will need to resolve in order to apply Klein's rule of decision principle in light of a value of legislative generality.

\section{A "Class of Cases"}

Closely related to the issue of legislative generality is the issue of what constitutes a "class of cases." As Justice Thomas noted in Patchak, the Klein Court specifically reaffirmed that Congress has the power to withdraw jurisdiction over a "class of cases." 252 Because the Gun Lake Act applied to cases relating to the Bradley Property, Thomas opined that it withdrew jurisdiction over a class of cases within the meaning of Klein..$^{253}$ Chief Justice Roberts did not deny this reading of Klein, instead arguing that, as a practical matter, the Gun Lake Act withdrew jurisdiction over just one case, Patchak's suit against the United States. ${ }^{254} \mathrm{He}$ concluded that the Gun Lake Act did not, therefore, withdraw jurisdiction over a "class of cases." 255 Although Roberts implies that a single case is not a class of cases, and Thomas implies that any number of cases greater than one is a class, both Roberts and Thomas carefully avoided defining what constitutes a class. As described below, a more nuanced approach than the ones suggested by Thomas or Roberts better explains what Klein's "class of cases" should mean.

\section{A Class of Cases v. a Single Case}

The simplest way to define a class of cases is to follow the line of reasoning suggested by Justice Thomas. Noting that the Gun Lake Act required the dismissal of more than one case, Thomas neatly concluded that it withdrew ju-

${ }^{250}$ MANDELKER ET AL., supra note 246, at 669-70 (“'[C]ourts often hold that a challenged law is special when it creates a 'closed class.' A class is closed rather than open if it is impossible, or extremely unlikely, that another person or entity will fall within the statutory classification in the future.").

${ }^{251} I d$. at 670 ("Conversely, courts tend to uphold classifications that are narrowly drawn if the class is 'open,' that is, if other people or entities may fall into the class in the future.").

252 Patchak v.Zinke, 138 S. Ct. 897, 906-07 (2018).

253 Id. at 909.

${ }^{254}$ Id. at 916-17 (Roberts, C.J., dissenting).

255 Id. at 918 . 
risdiction over a "class of cases." 256 Although he did not say so explicitly, Thomas's conclusion can be taken as implicitly assuming that any number of cases greater than one is a class within the meaning of Klein.

The major advantage of this suggested rule is that it is relatively easy to administer: whether a statute applies to a single case or to more than one case normally can be discerned from the text of a statute and its legislative context. Consider the statute that created a special exemption allowing the appointment of James Mattis as Secretary of Defense. ${ }^{257}$ As the language of the statute made clear, it was a "limited exception," applying "only to the first person appointed as Secretary of Defense" and to "no other person." 258 To erase all doubt about the bill's reach, its proponents introduced the bill as "a one-time exemption on behalf of an individual" that would not "permanently change the law."259 Just as the text and legislative context made clear that the Mattis waiver statute applied to one person, similarly, it will be easy to determine, for many statutes, whether they apply to a single case or more than one case.

However, even clear statutory language can give rise to grey areas. The legislation upheld in Bank Markazi, for example, deemed the assets of Bank Markazi to be the assets of Iran, but only for one particular, consolidated action involving nineteen judgments and more than a thousand victims. ${ }^{260}$ On one hand, the statute affected only a single pending case. But, on the other hand, because the single case was a consolidated action of nineteen judgments, it can also be viewed as more than one case. As this ambiguity reveals, a rule that distinguishes between a single case and more than one case does not neatly resolve all situations.

Another advantage of Thomas's bright-line rule is that it is consistent with the constitutional value of legislative generality. As noted, a value of legislative generality prevents the legislature from targeting an individual for special treatment, which is often associated with corruption, animus, favoritism, or other costs. ${ }^{261}$ A rule that prevents the application of a change in law to a single case advances the value of legislative generality by preventing the legislature from targeting an individual case and imposing these kinds of costs. A rule that distinguishes between a single case and any number of cases greater than one, however, is not a perfect fit with a value of legislative generality. Legislation that targets a group of identifiable individuals creates many of the same costs as

${ }^{256} I d$. at 910 (plurality opinion).

257 Act of Jan. 20, 2017, Pub. L. No. 115-2, 131 Stat. 6 (creating a special exception for James Mattis).

${ }^{258} I d$.

259163 Cong. ReC. H9,480 (daily ed. Jan. 13, 2017) (statement of Rep. Dan Newhouse).

${ }^{260}$ Bank Markazi v. Peterson, 136 S. Ct. 1310, 1326-27 (2016). This ambiguity was raised in the Bank Markazi Supreme Court oral argument. Transcript of Oral Argument at 5, Bank Markazi v. Peterson, 136 S. Ct. 1310 (2016) (No. 14-770).

261 Zoldan, Legislative Design, supra note 232, at 418-19, 426-42 (enumerating the costs associated with special legislation). 
legislation that targets a single individual. ${ }^{262}$ Because the legislature knows who will benefit or suffer from the targeted legislation, ${ }^{263}$ legislation targeting both an individual and a group of known individuals can be prompted by corruption, animus, favoritism, or other illegitimate motives. As a result, a rule that distinguishes between a single case and any number of cases greater than one will not prevent legislation creating many of the harms that a more nuanced value of legislative generality could address.

Weighed against these imperfect advantages, there are also significant drawbacks to a rule that turns on a precise number of cases. Defining a class of cases for the purposes of Klein in this way will often lead to an arbitrary distinction between statutes that are similar in a relevant way.

For example, consider again Robertson's Northwest Timber Compromise, which instructed the federal courts to interpret the environmental and land management statutes underlying three named lawsuits in favor of the suits' defendants. ${ }^{264}$ By requiring the court to interpret statutory terms in a particular way, Congress arguably encroached on the independence of the courts, usurping the judicial function. But, whatever the severity of the encroachment on the courts, it had little to do with the precise number of cases that were affected. Had the statute directed the court to interpret the generally applicable law for one particular lawsuit rather than three, the incursion into the judicial role would have been fundamentally the same. A Klein principle that prevents Congress from directing the result in a single case, but is powerless if Congress directs the result in two or three related suits, would be easily evaded and lead to arbitrary distinctions between similar situations. ${ }^{265}$

Finally, a Klein rule that distinguishes between a single case and any number of cases greater than one is contrary to the holding in Klein itself. The appropriations proviso invalidated in Klein did not merely require dismissal of Klein's case ${ }^{266}$ Rather, it required the dismissal of a group of cases that fit a particular description: that is, cases in which a plaintiff had prevailed in the Court of Claims, relying on evidence of an oath of loyalty, against the United

${ }^{262}$ People v. Canister, 110 P.3d 380, 381 (Colo. 2005) (invalidating as special statute applying to two people).

263 Zoldan, Reviving Legislative Generality, supra note 216, at 654 (noting that one cost of special legislation is legislative targeting).

${ }^{264}$ Robertson v. Seattle Audubon Soc'y, 503 U.S. 429, 437-38 (1992) (describing impact of Compromise on pending cases).

265 Conversely, there may be situations where a statute applies to one individual but appears justified in some way. In Nixon v. Administrator of General Services, 433 U.S. 425, 472, 477 (1977), the Court upheld a law confiscating the papers of former President Nixon because he was a "legitimate class of one."

266 Act of July 12, 1870, ch. 251, 16 Stat. 230, 235; see also Tyler, supra note 109, at 94-95 (noting that the appropriations proviso was intended to apply to multiple cases brought by former rebels). 
States. ${ }^{267}$ As a result, when the Klein Court distinguished the group of cases affected by the appropriations proviso from a "class of cases," it must have used "class of cases" to mean something other than any number of cases greater than one. Contrary to Thomas's argument, therefore, Patchak cannot be distinguished from Klein on the basis of the number of suits affected. If Klein is still good law, as Thomas suggested, then a "class of cases" must mean something other than any number of cases greater than one.

\section{A Class of Cases v. Pending Cases Only}

Klein itself suggests an approach to defining a "class of cases" that is superior to the distinction between a single case and any number of cases greater than one. When the Klein Court approved Congress's authority to withdraw jurisdiction from the federal courts in "a particular class of cases," 268 it contrasted this power with the appropriations proviso, which unconstitutionally prescribed a rule of decision to a court "in cases pending before it." 269 This statement can be read as expressing a concern not with the application of new law to pending cases (which is generally permitted under the Changed Law Rule), ${ }^{270}$ but rather as a concern with the application of new law to pending cases only. Under this reading of a "class of cases," the problem with the appropriations proviso was that there were no cases other than pending cases to which it could have applied. ${ }^{271}$

The modern Supreme Court has not followed this reading of Klein. As described above, the statute upheld in Bank Markazi explicitly applied to a pending case alone. ${ }^{272}$ Nevertheless, when the Supreme Court again addresses the rule of decision principle, it should consider adopting an approach that distinguishes between statutes that reach pending cases alone and statutes that reach both pending and future cases. Unlike the rule suggested by Thomas, this approach is easy for courts to administer in a principled way. This approach also coheres with the constitutional value of legislative generality; but, unlike a rule that places conclusive weight on the number of cases affected, it does so in a way that better accounts for the value of legislative generality's underlying

267 Act of July 12, 1870, ch. 251, 16 Stat. 230, 235.

268 United States v. Klein, 80 U.S. (13 Wall.) 128, 145 (1871).

${ }^{269} I d$. at 146.

${ }^{270}$ United States v. Schooner Peggy, 5 U.S. (1 Cranch) 103, 109 (1801) (upholding statute that changed the law in a case on appeal).

271 Act of July 12, 1870, ch. 251, 16 Stat. 230, 235 (applying retrospectively to pardons already offered and accepted); see also Tyler, supra note 109 at 94-95 (noting that the congressional proponent of the proviso estimated the government's liability to former rebels under the Abandoned and Captured Property Act at more than ten million dollars).

272 Bank Markazi v. Peterson, 136 S. Ct. 1310, 1318-19 (2016) (noting that statute at issue applied to a single consolidated case). 
concerns. And, unlike a rule that turns on whether a single case or more than one case is affected, this approach is consistent with Klein itself..$^{273}$

First, a Klein rule that permits statutes to apply to pending cases so long as it also applies to future, unknown cases is easy to administer. The statutory language itself will often determine conclusively whether a statute applies to pending cases only. In Bank Markazi, for example, the legislation deemed the assets of Bank Markazi to be the assets of Iran, but only for ongoing litigation. ${ }^{274}$ In that case it is easy to tell that the legislation applied to a pending case (or pending cases) and could not apply to future, unknown cases. Because this approach does not turn on the precise number of pending cases, it also eliminates grey areas created by an approach that focuses exclusively on the number of cases affected.

Second, as noted above, a rule that turns on whether one case or more than one case is affected aligns it with the value of legislative generality. ${ }^{275}$ However, for many of the reasons that legislation targeting a single individual has been called unjust, legislation that targets a group of identifiable individuals also can be considered unjust. For example, because the legislature knows who will benefit or suffer from the targeted legislation, legislation targeting both an individual and a small group of known individuals can be prompted by corruption, animus, favoritism, or other illegitimate motives. ${ }^{276}$ As a result, a rule that prevents the application of new law to a fixed universe of cases that are known because they are already pending will be more closely aligned with a value of legislative generality than a rule that is powerless when a statute targets two or more pending cases.

An approach that turns on whether a change in law applies to pending cases only rather than on the absolute number of individuals targeted by the legislation also comports with the approach taken by state courts enforcing restrictions on targeted legislation under state constitutional law. When a statute creates a closed class, one that cannot be augmented in the future, state courts

273 There are other plausible definitions of the term "class of cases." One alternative is that Klein used the term in the sense of "class legislation," a constitutional doctrine important until the early 20th century. Class legislation is "legislation that singles out a class for special treatment without a concomitant public purpose." Zoldan, The Equal Protection Component, supra note 218, at 505. Impermissible class legislation is distinguished from permissible legislation that legislates for a natural or real class. People v. Canister, 110 P.3d 380, 383 (Colo. 2005). On this view, Klein may have held that the proviso was impermissible class legislation because it singled out a group of cases that was a subpart of a real or natural class. The class legislation theory is no longer enforced as a stand-alone principle under the federal Constitution. Zoldan, The Equal Protection Component, supra note 218, at 524-25.

274 Bank Markazi, 136 S. Ct. at 1319.

275 See supra Section III.B.

276 Zoldan, The Equal Protection Component, supra note 218, at 496 ("After all, a statute that singles out a small, determinable group raises many of the same concerns - like favoritism, animus, or encroachment on the judicial function - that attend individualized legislation."). 
often invalidate the legislation as impermissibly special. 277 When legislation creates a class that includes known individuals, but which also could apply to others in the future, courts tend to uphold it because it creates an open class. ${ }^{278}$ Legislation that affects pending cases maps on to this open-class / closed-class dichotomy. When legislation affects pending cases alone, it creates a closed class, whose members have been selected by the legislature for special treatment, perhaps with an impermissible motive. By contrast, when legislation applies to pending and future cases, the legislature acts, in part, from behind a veil of ignorance, unaware of the full spectrum of cases that will be affected by the change in law. ${ }^{279}$ The fact that the legislature cannot know everyone who will be affected by a change makes it less likely that the legislature will use this instrument to target known individuals because they cannot do so without risking unintended applications.

Third, unlike a rule that distinguishes between a single case and any number greater than one, an approach that distinguishes between pending cases only and pending and future cases is consistent with Klein itself. As noted, the Klein Court distinguished between "a particular class of cases," over which Congress has complete control, and a statute that unlawfully prescribes a rule of decision to the courts "in cases pending before it." 280 This distinction demonstrates that the Klein Court considered it possible that withdrawing jurisdiction may be unlawful even if more than one case is affected by the change in law.

Finally, this approach also makes sense of a somewhat cryptic passage in Klein, in which the Court distinguished the appropriations proviso from the statute it previously upheld in Wheeling Bridge. ${ }^{281}$ Wheeling Bridge arose from the Court's previous injunction against the operation of a bridge, which the Court enjoined after finding that the bridge was a nuisance. ${ }^{282}$ After the operation of the bridge was enjoined, however, Congress enacted a statute that declared the bridge was not a nuisance. ${ }^{283}$ In Wheeling Bridge, the Court upheld

277 Canister, 110 P.3d at 384 ("By contrast, a class that is drawn so that it will never have any members other than those targeted by the legislation is illusory, and the legislation creating such a class is unconstitutional special legislation."); Sierra Club v. Dep't. of Transp., 202 P.3d 1226, 1276 (Haw. 2009) (invalidating a statute as a special law when, although framed as a general law, in reality applied only to a closed class of one).

278 MANDELKER ET AL., supra note 246, at 669-71 (discussing open class/closed class distinction).

279 Adrian Vermeule, Veil of Ignorance Rules in Constitutional Law, 111 YALE L.J. 399, 399 (2001) (arguing that the Constitution contains veil of ignorance rules that subject "decisionmakers to uncertainty about the distribution of benefits and burdens that will result from a decision").

${ }^{280}$ United States v. Klein, 80 U.S. (13 Wall.) 128, 145-46 (1871).

281 Pennsylvania v. Wheeling \& Belmont Bridge Co., 59 U.S. (18 How.) 421, 440 (1855).

282 Id. at 447.

${ }^{283} I d$. at 422 . 
the application of the new law to the pending case, which resulted in the dissolution of the injunction. ${ }^{284}$

In Klein, the Court reaffirmed its previous holding in Wheeling Bridge; the Court distinguished this previous case on the ground that, after the new law declared the bridge not to be a nuisance, the Court "was left to apply its ordinary rules to the new circumstances created" by the change in law. ${ }^{285}$ As a result, no "arbitrary rule of decision was prescribed in that case." 286 By contrast, the appropriations proviso was defective because it did not create new circumstances; instead, it required the Court to apply the law to particular pending cases. In making this distinction, Klein can be read to distinguish between a law that applies to pending cases alone and, on the other hand, a change in law that applies to pending cases and future cases. On this reading, the Wheeling Bridge statute was lawful because it declared that the bridge was not a nuisance-not only for the injunction that was then in force-but also for any future lawsuits claiming that the bridge was a nuisance. By contrast, the Wheeling Bridge statute would have been defective had it declared the bridge lawful only for the purposes of the injunction that was then in force.

In sum, when the Supreme Court again addresses the definition of "class of cases" in the context of Klein, it should revive the distinction between statutes that apply to pending cases only and, on the other hand, statutes that apply both to pending and future cases. A definition that carries this distinction will be easy for courts to administer because statutory language and legislative context normally make clear whether a statute affects pending cases alone. This approach, moreover, is consistent with a value of legislative generality because it is analogous to the open-class / closed-class distinction often used to define impermissible special legislation. And finally, this approach not only is consistent with Klein, but it also makes sense of Klein's puzzling passage distinguishing Wheeling Bridge.

\section{The Government's Sovereign Immunity}

In their concurrences, Justices Ginsburg and Sotomayor took an approach to Patchak that avoided all of the thorny issues discussed above. Instead, they opined that the Gun Lake Act had the functional effect of asserting or restoring the government's sovereign immunity because it required the federal courts to dismiss suits relating to the Bradley Property. ${ }^{287}$ Because some suits relating to the Bradley Property would lie against the United States, and because the United States can always assert its immunity from suit, the Gun Lake Act was valid

${ }^{284}$ Id. at 431-32.

285 Klein, 80 U.S. at $146-47$.

286 Id. at 146.

287 Patchak v. Zinke, 138 S. Ct. 897, 912-14 (2018) (Ginsburg, J., concurring \& Sotomayor, J., concurring). 
even though it directed a federal court to dismiss a particular, pending suit. ${ }^{288}$ The plurality did not address this argument; moreover, the Chief Justice failed to counter the ultimate constitutional point asserted in these concurrences. Instead, he retreated to a statutory interpretation argument, opining that the Gun Lake Act did not, in fact, assert the government's sovereign immunity. ${ }^{289}$

\section{The Limits of Sovereign Immunity}

It is true that the Court has described Congress's power to assert the government's sovereign immunity in absolute terms. In a typical statement of this principle, the Court has held that the United States subjects itself to suit only as "an act of grace." ${ }^{290}$ As a result, it may be inferred, Congress's subsequent decision to withdraw jurisdiction from the federal courts over a suit against the United States always will be honored by the courts. ${ }^{291}$

But, despite strong rhetorical statements about the government's consent to be sued, there is reason to doubt that the government's sovereign immunity extends as far as Ginsburg and Sotomayor suggest. Most obviously, the scope of immunity they describe is at odds with Klein itself. The statute invalidated in Klein required federal courts to dismiss suits that only could be asserted against the United States. ${ }^{292}$ Nevertheless, the Klein Court invalidated the proviso. If Klein is good law, therefore, sovereign immunity, whatever its scope, does not insulate a statute simply because it requires dismissal of suits against the United States. The Klein Court made this point explicitly when it rejected the government's argument that "the right to sue the government ... is a matter of favor." 293 The Court emphasized, instead, that "it is as much the duty of the government as of individuals to fulfil its obligations." 294

Doctrine aside, Ginsburg and Sotomayor's concurrences are still too broad: it cannot be true that any statute terminating pending suits is saved from constitutional infirmity so long as it has the effect of dismissing claims against the United States. Imagine a statute that requires the federal courts to dismiss all claims asserted by a particular religious group against the United States. Be-

${ }^{288}$ Id. at 912-913 (Ginsburg, J., concurring).

${ }^{289}$ Id. at 921-22 (Roberts, C.J., dissenting).

290 District of Columbia v. Eslin, 183 U.S. 62, 65 (1901).

291 Patchak, 138 S. Ct. at 912 (Ginsburg, J., concurring) (citing Eslin, 183 U.S. at 65-66).

292 Act of July 12, 1870, ch. 251, 16 Stat. 230, 235 (providing for the dismissal of suits against the United States).

293 United States v. Klein, 80 U.S. (13 Wall.) 128, 144 (1871).

${ }^{294}$ Id. Here, the Supreme Court paraphrased a line from President Lincoln's First Annual Message: "It is as much the duty of Government to render prompt justice against itself, in favor of citizens, as it is to administer the same between private individuals." Abraham Lincoln, President of the U.S., Annual Message to Congress (Dec. 3, 1861), in Cong. Globe, 37th Cong., 2d Sess. 1, 2 (1861). An excerpt from this speech adorns the side of the Washington, D.C. building that houses both the United States Court of Federal Claims and the United States Court of Appeals for the Federal Circuit. 
cause this statute requires the dismissal of suits against the United States, it would "restore[] the Federal Government's sovereign immunity" 295 as much as did the Gun Lake Act. But, of course, this statute also would violate other constitutional provisions. ${ }^{296}$ As this example demonstrates, simply because a statute effectively asserts or "restores" the government's sovereign immunity does not determine whether it also generates other constitutional problems. As a result, the fact that the Gun Lake Act required the dismissal of suits against the government does not determine whether it also violates the Constitution by directing a federal court to enter judgment in a pending case. If the Constitution prohibits Congress from directing the result in a pending case, then a statute that does so is not redeemed by the fact that it also terminates suits against the government. $^{297}$

\section{A Principle Against Self-Dealing}

The expansive vision of sovereign immunity proffered by Justices Ginsburg and Sotomayor turns out to be implausibly broad. It is possible, however, to imagine a more modest version of sovereign immunity. In a diverse set of constitutional contexts, ${ }^{298}$ the Supreme Court has declined to uphold statutes that reflect governmental self-dealing-that is-legislation that repudiates an obligation of the government in a pending dispute. ${ }^{299}$ A principle that disfavors legislative self-dealing is more modest than Justices Ginsburg and Sotomayor's version of sovereign immunity because it protects the prerogatives of legislative power while also creating space for the independent operation of the feder-

295 Patchak, 138 S. Ct. at 912 (Sotomayor, J., concurring).

296 This statute would likely violate the Constitution's First Amendment, among other provisions. For an Article III example, consider the possibility of Congress creating a second Supreme Court authorized to hear appeals from judgments in which claims were asserted against the United States, but which is required to dismiss all cases in which the United States prevailed in the lower court. This provision would result in the dismissal of claims against the United States, but it would also arguably violate Article III by creating a court of last resort other than the "one Supreme Court" provided for in the Constitution. U.S. ConST. art. III, $\S 1$.

${ }^{297}$ For a similar reason, Justice Breyer's concurring opinion that Congress may always lawfully "confirm" administrative action that is itself constitutional is unpersuasive. For example, while an agency head may lawfully appoint inferior officers, it is unconstitutional for Congress itself to appoint inferior officers. U.S. CONST. art. II, § 2. As a result, whether a statute "confirms" administrative action does not determine whether it is otherwise unconstitutional.

${ }^{298}$ E.g., U.S. Tr. Co. v. New Jersey, 431 U.S. 1, 1 (1977) (refusing to defer to states' decision to breach bond obligations); Perry v. United States, 294 U.S. 330, 350 (1935) (holding that the United States "is [not] free to ignore that pledge and alter the terms of its obligations in case a later Congress finds their fulfillment inconvenient"); Carmell v. Texas, 529 U.S. 513,514 (2000) (retrospective rules that inure only to the benefit of the state implicate ex post facto concerns).

${ }^{299}$ For an argument that the Klein rule of decision principle reflects a constitutional principle against self-dealing, see Zoldan, Klein, supra note 20, at 2190-94. 
al courts. Examining some of the Court's self-dealing cases suggests a principled way for courts to determine whether to uphold a statutory change in law that has the effect of terminating suits against the United States.

In Winstar, the government was liable for breaching an agreement with private parties because Congress's repudiation of the government's agreement reflected self-dealing. ${ }^{300}$ The government was engaged in self-dealing because the statute that repudiated its contract appeared to be an act of an interested party rather than the act of a regulating sovereign. ${ }^{301}$ The plurality suggested a sliding scale to determine whether the government may break its promise in the course of regulating. ${ }^{302}$ A statute that impairs the government's obligations, but which does so only incidental to "the accomplishment of a broader governmental objective," will be permitted as a disinterested, sovereign act. ${ }^{303}$ However, the "greater the Government's self-interest ... the more suspect becomes the claim that its private contracting partners ought to bear the financial burden." 304 And if "a substantial part of the impact of the Government's action rendering performance impossible falls on its own contractual obligations," the government must honor its agreement. ${ }^{305}$

Similarly, in Perry v. United States ${ }^{306}$ the Court rebuffed Congress's attempt to claim immunity from suit for reneging on an obligation. ${ }^{307}$ The Court held that the United States is not free to "alter the terms of its obligations in case a later Congress finds their fulfillment inconvenient." ${ }^{308}$ Indeed, while Congress has a relatively free hand to regulate contractual obligations generally, this freedom does not extend to the government's power "to alter or repudiate the substance of its own engagements." 309 The Court specifically rejected the government's argument that, as a sovereign, Congress could not be bound to its contractual obligations. ${ }^{310}$ The power to enter into binding contracts is itself a sovereign power, the Court reasoned; therefore, disclaiming a previous contractual obligation is as much a repudiation of sovereignty as abiding by it. ${ }^{311}$

${ }^{300}$ United States v. Winstar Corp., 518 U.S. 839, 896 (1996) (describing that statutes are sometimes "tainted by a governmental object of self-relief").

${ }^{301} I d$. at 902-03 (distinguishing between public and general acts and, on the other hand selfinterested acts).

302 Id. at 896.

303 Id. at 898 .

${ }^{304} I d$. (emphasis added).

${ }^{305} \mathrm{Id}$.

306 Perry v. United States, 294 U.S. 330 (1935).

307 Id. at 350.

$308 I d$.

${ }^{309} I d$. at 350-51 (emphasis added).

$310 I d$. at 353 .

311 Id. at 354 ("The fact that the United States may not be sued without its consent is a matter of procedure which does not affect the legal and binding character of its contracts."). 
In these cases, as well as in other contexts, ${ }^{312}$ the Court has refused to apply a change in law that would have had the effect of benefitting the government in pending cases when the new law reflected the government's self-interest. In these cases, the Court took pains to emphasize that it will respect, and defer to, laws that apply even-handedly to the government and other parties. Whether a statute reflects disinterested regulation rather than self-interest depends on the extent to which the statute accomplishes some goal other than simply relieving the government of an obligation. ${ }^{313}$

A principle against governmental self-dealing, as suggested by Winstar, Perry, and similar cases, can guide courts considering whether to apply a new law purporting to terminate, because of the government's sovereign immunity, a suit pending against the United States. Consider how a principle against selfdealing could be used to evaluate Patchak. The surest effect of the Gun Lake Act was to save the government from the burden of defending itself in the pending suit brought by Patchak. ${ }^{314}$ Like the statutes invalidated in Winstar and Perry, therefore, the Gun Lake Act repudiated the government's obligation under existing law. On the other hand, Interior's decision to take the Bradley Property into trust did more than alter the government's obligation; because it arguably reached all suits relating to the Bradley Property, the burden of the Gun Lake Act did not fall exclusively on Patchak. ${ }^{315}$ Moreover, even if, as a practical matter, the statute affected Patchak's lawsuit alone, unlike the Winstar and Perry statutes, the Gun Lake Act created only a modest benefit for the United States. Other than the cost of defending against Patchak's suit, it did not benefit the government financially. Instead, the stated and likely reason for the government's action was to benefit the Match-E-Be-Nash-She-Wish. ${ }^{316}$ On this view of the government's action, the Gun Lake Act can be seen as part of the government's effort to assist the tribe rather than to self-deal.

The Winstar-Perry analysis will not always provide an easy answer to difficult questions about the purposes and effects of the government's actions. Nevertheless, evaluating a claim of sovereign immunity in light of a principle against self-dealing should be attractive to courts resolving similar future cases. An approach based on a principle against governmental self-dealing resonates

312 E.g., U.S. Tr. Co. v. New Jersey, 431 U.S. 1, 1 (1977) (refusing to defer to states' decision to breach bond obligations); Perry, 294 U.S. at 350 (holding that the United States is not "free to ignore that pledge and alter the terms of its obligations in case a later Congress finds their fulfillment inconvenient"); Carmell v. Texas, 529 U.S. 513, 514 (2000) (retrospective rules that inure to the benefit of the government only implicate Ex Post Facto Clause concerns).

313 United States v. Winstar Corp., 518 U.S. 839, 900 (invalidating statute that benefitted the government at the expense of private parties); Perry, 294 U.S. at 354 (same).

${ }^{314}$ Patchak v. Zinke, 138 S. Ct. 897, 909-10 (2018) (describing the effect of the Gun Lake Act).

315 Id. (describing the possible broader reach of the Gun Lake Act).

${ }^{316} I d$. (describing the purpose of Interior's decision to take the property into trust). 
with other areas of constitutional law. It preserves both the prerogative of Congress to determine its exposure to liability and the power of courts to decide pending cases. And perhaps most importantly, this approach rejects an implausibly broad vision of sovereign immunity while still allowing the government to assert immunity when it regulates disinterestedly.

\section{CONCLUSION}

The core of judicial independence is the power of the courts to resolve cases pending before them without legislative interference. But, when Congress directs the courts to reach particular results in pending cases, it blurs the line between the judicial and legislative powers. The Supreme Court has not defended the core of judicial independence, instead upholding increasingly intrusive statutes that direct the courts to enter judgment for particular parties. Although the line between the judicial power and legislative power is surely fuzzy, the Court can, and should, refine its approach to ensure that the core of judicial independence is not lost altogether. The Court should not apply a change in law to pending cases when the law fails to set policy, when it singles out an individual for special treatment, when it withdraws jurisdiction solely for the purpose of terminating pending cases, or when it reflects governmental selfdealing. Observing these limitations on Congress's power to direct the result in pending cases allows Congress ample room to fulfill its lawmaking function. But, unlike the Court's current approach, it also preserves the courts' role to actually decide cases rather than just enter judgment at the direction of Congress. 